NBER WORKING PAPER SERIES

\title{
CAN NUDGES INCREASE TAKE-UP OF THE EITC?: EVIDENCE FROM MULTIPLE FIELD EXPERIMENTS
}

\author{
Elizabeth Linos \\ Allen Prohofsky \\ Aparna Ramesh \\ Jesse Rothstein \\ Matt Unrath \\ Working Paper 28086 \\ http://www.nber.org/papers/w28086 \\ NATIONAL BUREAU OF ECONOMIC RESEARCH \\ 1050 Massachusetts Avenue \\ Cambridge, MA 02138 \\ November 2020
}

We are grateful to our partners for their extraordinary work in administering these interventions and their commitment to informing policy through rigorous research. At the California Franchise Tax Board, we thank Sean McDaniel, Monica Trefz, Ian Kiltz, Chad Angaretis, Silvano Guitierrez, Bob Schlie, and Xudong Chen, and especially Julie Moreno. At the California Department of Social Services, we thank Alexis Fernandez, Kim McCoy-Wade, Jianjun Chen, Brittney Gossard, and Akhtar Khan. We also thank our multiple CalFresh county partners, Alberto Garcia, Deanna Abrahamian, Todd Blair, Ashley Arnold, Gladys Deloney, Yunny Tai, Margareta Hodzic, and Idelle Villarreal. We also thank Trevor Rogers, Sebastien Chaubard, Timothy Merritt and Josh Fryday at Golden State Opportunity for all of their help in administering these studies. And we thank Pete Manzo and Nalleli Sandoval at the United Way of California, along with staff from United Way Bay Area, United Way of the Wine Country, and Orange County United Way for their input along the way.

Finally, we are grateful for financial support from the Abdul Latif Jameel Poverty Action Lab, Arnold Ventures, Tipping Point Community, the University of Wisconsin Institute for Research on Poverty, the Horowitz Foundation for Social Policy, and the James Irvine Foundation. All errors should be attributed to the authors. The analyses reported herein were performed with the permission of CDSS and FTB, who had the opportunity to review for disclosure risk before they were released. The opinions and conclusions expressed herein are solely those of the authors and should not be considered as representing the policy of the collaborating department, agency, any department or agency in the California government, or the National Bureau of Economic Research.

This research was conducted through the California Policy Lab at UC Berkeley. We thank Evan White, Christopher Campos, Konrad Franco, John Iselin, Sree Kancherla, and Charles Davis, who were instrumental in making this project a success. We also thank Professor Jacob Goldin and Taylor Cranor from Stanford Law School and Akshay Ravikumar Kalose from Stanford University who were critical to launching our CalFresh experiments in 2018.

NBER working papers are circulated for discussion and comment purposes. They have not been peerreviewed or been subject to the review by the NBER Board of Directors that accompanies official NBER publications.

(C) 2020 by Elizabeth Linos, Allen Prohofsky, Aparna Ramesh, Jesse Rothstein, and Matt Unrath. All rights reserved. Short sections of text, not to exceed two paragraphs, may be quoted without explicit permission provided that full credit, including (C) notice, is given to the source. 
Can Nudges Increase Take-up of the EITC?: Evidence from Multiple Field Experiments Elizabeth Linos, Allen Prohofsky, Aparna Ramesh, Jesse Rothstein, and Matt Unrath NBER Working Paper No. 28086

November 2020

JEL No. D91,H24,H26,I38

\section{ABSTRACT}

The Earned Income Tax Credit (EITC) distributes more than $\$ 60$ billion to over 20 million lowincome families annually. Nevertheless, an estimated one-fifth of eligible households do not claim it. We ran six pre-registered, large-scale field experiments to test whether "nudges" could increase EITC take-up ( $\mathrm{N}=1$ million). Despite varying the content, design, messenger, and mode of our messages, we find no evidence that they affected households' likelihood of filing a tax return or claiming the credit. We conclude that even the most behaviorally informed low-touch outreach efforts cannot overcome the barriers faced by low-income households who do not file returns.

Elizabeth Linos

University of California at Berkeley

2607 Hearst, Room 312

Berkeley, CA 94720

elinos@berkeley.edu

Allen Prohofsky

Franchise Tax Board

PO Box 942857

Sacramento, CA 95827-0500

Allen.Prohofsky@ftb.ca.gov

Aparna Ramesh

University of California, Berkeley

2521 Channing Way \#5555

Berkeley, CA 94720

aparna.ramesh@berkeley.edu
Jesse Rothstein

Goldman School of Public Policy and

Department of Economics

University of California, Berkeley

2607 Hearst Avenue \#7320

Berkeley, CA 94720-7320

and NBER

rothstein@berkeley.edu

Matt Unrath

Goldman School of Public Policy

University of California, Berkeley

2607 Hearst Avenue \#7320

Berkeley, CA 94270-7320

unrath@berkeley.edu 


\section{Introduction}

The Earned Income Tax Credit (EITC) is a critical income support for working families. In 2019, 25 million households received about $\$ 63$ billion nationwide, with an average benefit of approximately $\$ 2,500$. Numerous studies have documented the EITC's beneficial effects on work, income, and poverty; children's educational achievement and attainment; and adult and infant health (see reviews in Hoynes and Rothstein, 2016; Nichols and Rothstein, 2016). Despite these benefits, the IRS estimates that one in five eligible households do not take up the program (IRS, nd). For eligible families with the lowest incomes, take-up may be much lower, with approximately one in two households foregoing their cash benefit (Jones, 2014; Plueger, 2009).

The academic literature in various disciplines has proposed that learning, compliance, and psychological costs can explain incomplete take-up of government benefits (Finkelstein and Notowidigdo, 2019; Herd and Moynihan, 2019; Currie, 2006; Moffitt et al., 1983). First, to claim the EITC, households must overcome the learning costs associated with discovering the credit exists and determining whether they are eligible. Second, for families aware of the credit, the filing process can be confusing, complex, and burdensome. Previous research suggests that the direct and indirect compliance costs of filing, difficult for the average tax filer to navigate, may be especially burdensome for low-income families (Herd and Moynihan, 2019; Goldin and Liscow, 2018; Bhargava and Manoli, 2015; Currie, 2006). Third, even if learning and compliance costs are overcome, the target population may face psychological barriers that inhibit take-up. Although the EITC is thought to carry less stigma than other benefit programs (Halpern-Meekin et al., 2015), a potential recipient may nevertheless distrust government or face psychological stressors that prevent them from carrying out plans to file a return (Hovland and Weiss, 1951; Pornpitakpan, 2004). Distrust, for example, may be a particular challenge for EITC outreach. Outreach messages often include promises of free cash that can be hard to distinguish from scams to which families are frequently exposed. The relative importance of all these potential explanations for the take-up gap remains largely unexplored.

"Nudges" - small changes to the choice architecture surrounding a decision that aim to alter people's behavior without meaningfully changing incentives - have been used to address many of these barriers, with substantial impacts on enrollment decisions across a wide array of policy contexts (Benartzi et al., 2017; Hallsworth et al., 2017; Thaler and Sunstein, 2009; Thaler and Benartzi, 2004; Madrian and Shea, 2001; Dellavigna and Linos, 2020). For example, nudges have been used to increase take-up of the Supplemental Nutrition Assistance Program (SNAP) (Finkelstein and Notowidigdo, 2019), citizenship applications (Hotard et al., 2019), and even college enrollment through increasing completion of the Free Application for Federal Student Aid (FAFSA) (Bettinger et al., 2012). However, the evidence is not unambiguous; recent studies suggest that nudges may be ineffective in other settings or may fail to scale (Camerer et al., 2018; Bird et al., 2019; Castleman 
et al., 2019; Bergman et al., 2019).

Studies on EITC take-up have also yielded mixed results. Bhargava and Manoli (2015) find that IRS notifications to eligible taxpayers increased EITC claiming. Guyton et al. (2017), on the other hand, find positive but much smaller effects of outreach on tax filing rates, with an effect size of about 0.5 percentage points. Kopczuk and Pop-Eleches (2007) find that the availability of tax preparation software increased EITC claiming. Chetty et al. (2013) similarly show that the availability of nearby paid tax preparation services in a neighborhood predicts knowledge about the program and usage. However, Cranor et al. (2019) find that mandating employers to inform employees about their potential eligibility for the EITC had no effect on EITC take-up.

It is noteworthy that many successful nudge studies focused on populations who already had some interaction with the government. For example, both the Bhargava and Manoli (2015) and Bettinger et al. (2012) interventions were conducted among taxpayers who had already filed a return and only needed to be nudged to complete additional forms covering similar material. Similarly, Meiselman (2018) demonstrates that nudges increase filing of city tax returns amongst those who have already filed federal income taxes. Finkelstein and Notowidigdo (2019) contacted seniors who were already enrolled in Medicaid, but though eligible, failed to enroll in SNAP. It is not clear whether these kinds of nudges would work on those with fewer existing interactions. That is, for those who do not already file or who may have limited positive interactions with government, the learning, compliance, and psychological costs associated with EITC take-up may be much higher.

To contribute to the growing evidence on whether nudges "work" and for whom, and to tease out potential theoretical mechanisms that may explain barriers to take-up, we conducted six largescale, pre-registered randomized controlled trials in California in 2018 and 2019. These trials were carried out in collaboration with the California tax agency (the Franchise Tax Board, or FTB), state and local agencies that administer SNAP in California (CalFresh), and a large NGO dedicated to statewide EITC outreach (Golden State Opportunity). All of our trials aimed to increase take-up of California's state EITC (CalEITC), introduced in 2015. Because FTB believed that most eligible tax filers already claimed the EITC, and because many families eligible for the CalEITC do not face requirements to file state returns, our efforts focused on reaching families that might not already be filing California tax returns.

The CalEITC supplements the federal credit, as do similar programs in 25 other states (Nichols and Rothstein, 2016). Unlike other states' credits, the California credit does not simply magnify the federal schedule. It is more concentrated at the lowest incomes, where it is worth as much as $\$ 3,000$ per year. Figure 1 shows how the federal EITC and the CalEITC relate to family income for a single parent with two children; schedules vary for other family types but have similar shapes. For families with earnings around $\$ 7,000$, the combined federal and state credits can be worth as much as $\$ 5,500$, increasing family resources by close to $80 \%$. 
To claim the federal and state EITCs, families must file income tax returns, a potentially complex process. Many families who qualify for the credit are otherwise not required to file returns because their incomes fall below the thresholds that trigger filing requirements. Therefore, to claim the credit for the first time, families might have to engage with a tax system with which they have never interacted. Policymakers in California continue to be concerned that, absent outreach and education, many families will not claim the credits for which they are eligible. Iselin et al. (2020) find that the take-up rates among eligible CalFresh participants is $50 \%$ for the CalEITC and $70 \%$ for the federal EITC, and that only about one-third of eligible non-claimants of either credit file tax returns at all.

Surveys of potentially eligible families demonstrate that many are unaware of the credit and its specific eligibility parameters, validating this concern. One survey found that only two-thirds of families who received food stamps had heard of the federal EITC, and as few as one in three low-income parents who identified as Hispanic had heard of the credit (Phillips, 2001). While this survey is from 2000, the estimated national EITC participation rate has been remarkably consistent since the 2000s, remaining at roughly 75 to 80 percent (Jones, 2014; IRS, nd). Much of the evidence on EITC awareness focuses on those low income households that are already filing their taxes. Even among this population, surveys and interviews of filers at low income tax sites and other tax preparation sites find that while most associate filing taxes with a refund (Halpern-Meekin et al., 2015; Smeeding et al., 2000), only about half are aware of the EITC itself (Bhargava and Manoli, 2015). A minority are able to identify the mechanisms as to why they are receiving a refund or the benefit structure itself (Smeeding et al., 2000; Chetty et al., 2013).

Since it is more difficult to identify and survey non-filers, there is limited evidence about their awareness of, and familiarity with, the EITC. Nevertheless, there is reason to expect that they are less aware of the credit. For example, using a nationally representative sample including both filers and non-filers, Phillips (2001) finds that awareness of the EITC is lower among those with very low incomes, who are unlikely to file tax returns absent the EITC, than among those with somewhat higher incomes. Consistent with this, Blumenthal et al. (2005) find that only about 35\% of EITC-eligible households who were not required to file tax returns, due to low incomes, in tax year 1988 did so. More recent evidence confirms that substantial majorities of EITC eligible nonclaimants did not file tax returns at all (Plueger, 2009; Beecroft, 2012). This suggests that awareness of the EITC is lower among non-filers, but more research is needed both on this question and about how to reduce the burdens that these households face in claiming the EITC. Our study is motivated by the hypothesis that lack of awareness about the credit, the likely benefit amount, and where to seek help play at least some role in explaining incomplete take-up among this population.

We used six randomized trials, several with multiple treatment arms, to test a range of outreach messages that our partners sent to potentially eligible households. Our messages aimed to inform recipients of their potential eligibility for the federal and state EITCs and to encourage them to 
file a tax return. They were delivered by postal mail or by text message, and generally resembled the type of outreach efforts that public agencies often make to potential users of their services, though we strove to use best practice in terms of using clear and simple language. Other outreach efforts administered by our partners or other organizations during the same tax seasons, such as billboards, public events or traditional advertisements, were much lower-touch and would have affected our treatment and control groups similarly.

Subjects for our studies were drawn from participant lists for the CalFresh program and from a marketing database that included people with little or no existing interaction with government. None of the studies conditioned on filing taxes, and one conditioned on not having filed taxes in any of the three previous years. Each study was randomized, and we linked treatment and control rosters to FTB tax records. We report estimates for two primary outcomes, measured at the household level: Whether anyone in the household appeared (as filer or spouse) on a California tax return, and whether anyone appeared on a state or federal return including an EITC claim. Results are similar if we examine only CalEITC claiming.

Table 1 describes the six studies; the Appendix includes copies of each of the treatments. Each arm in our studies was designed to test a set of hypotheses, drawn from the literature on administrative burdens and ordeals (discussed above) about why people may fail to take up this available benefit. Specifically, the experiments aimed to reduce learning, compliance, and/or psychological costs associated with EITC participation via scalable, low-touch nudges. All studies included a control group that received no message, ${ }^{1}$ and all treatment arms provided information about the program and its value. If eligible households did not know about the program or did not know about the potential amounts they were likely to receive, we hypothesized that receiving this information would reduce learning costs and therefore increase take-up.

Treatment arms in Studies 3, 4, and 5 tested the impact of providing additional information about how to obtain help in filing a return, which targeted compliance costs. Specifically, if people knew about the EITC and understood the potential benefits, but the process was too burdensome, we hypothesized that providing individuals with detailed information about how to obtain help with tax preparation would reduce compliance hurdles and increase take-up. We pointed individuals to existing support services, as these represented the most scalable interventions. In Study 3 , we directed people to online resources, to text-based assistance, or to a hotline. In Studies 4 and 5, we provided detailed information about a local Volunteer Income Tax Assistance (VITA) site that provides free, in-person tax preparation assistance to low-income households.

To test whether psychological costs associated with source credibility might affect take-up de-

\footnotetext{
${ }^{1}$ It is possible that a member of the control group for one study was in the treatment group for another. The randomization design, discussed below, explicitly stratified on other treatment assignments where possible, to ensure a precisely zero correlation between treatment statuses in the different studies. We present analyses of each study separately. Analyses that use the overlapping samples to explore potential interactions among the different treatments show no evidence of any such interactions.
} 
cisions, treatment arms in Studies 2 and 4 delivered the same information in different formats and via different messengers. Since the notifications informed households that they were eligible to receive free money, we were concerned that households might distrust the information or assume it was a scam. We hypothesized that communication from a government agency and information presented in more formal formats would increase source credibility and reduce distrust. In Study 2 , we varied the messenger to test whether receiving information from a government agency was more effective than receiving the same information from a non-profit. We made the difference in messenger salient by changing the logos, signatures, and return addresses on the letters. In both Study 2 and Study 4, we also explored source credibility by sending the same information in both formal and informal formats. The formal treatments adopted the design used for federal tax communications and in other EITC nudging experiments to communicate with taxpayers about the EITC (e.g., Bhargava and Manoli, 2015). In the "informal" format, we used styles, images, and colors similar to those used in marketing materials employed by other statewide outreach efforts. In both cases, we used communication designs that could plausibly be scaled by a government agency. Studies 5 and 6 also aimed to enhance source credibility by delivering messages from local county welfare offices with which recipients regularly interacted, using similar wording as the agencies' other outreach messages.

Despite testing a range of interventions designed to leverage many of the behavioral explanations for incomplete take-up, we found that none of our interventions had substantively or statistically meaningful effects on tax filing or EITC claiming. Our messages were received; we find relatively high engagement with websites linked to in the messages. Nevertheless, in each of our trials, we can reject effects as large as the average nudge effect in a recent meta-analysis of nudge studies reviewed by Dellavigna and Linos (2020).

The existing evidence demonstrates that information-focused "nudge" interventions could have been effective. Our designs resemble interventions studied by other researchers that have found significant positive effects on take-up. For example, Bhargava and Manoli (2015) study an intervention that involved the IRS sending a single mailing to tax filers who had not claimed the EITC, and find that better-designed formats lead to higher rates of claiming. Guyton et al. (2017) also study the effect of a single mailed reminder, while Beecroft (2012) studies the impact of a postcard-sized mailer about the EITC sent to social service program participants. Finkelstein and Notowidigdo's (2019) study of SNAP participation involved sending one mailing and one follow-up postcard; their "Information Plus Assistance" group included on these documents a phone number for a non-profit organization which subjects could call for enrollment assistance, which resembles the the offers of assistance we test in our studies 3, 4, and 5 . We believe that the difference in our results largely reflects the difficulty of the task that people are being nudged to perform. For low-income households who do not file taxes, the hurdle of submitting a tax return may be too big for a simple outreach effort, no matter how well designed or behaviorally informed, 
to overcome. ${ }^{2}$ Getting families over this hurdle evidently requires more than just information and pointers to existing assistance.

It is important for the field to grapple with null findings in the same way it grapples with negative and positive findings. Our study improves our understanding of both the promise and limitations of behavioral interventions for low-income populations. It thereby makes a major contribution to the scholarship on behavioral science and the literature on incomplete take-up of means-tested programs; it should also inform potential policy reforms related to outreach efforts and tax administration. While nudges are a potentially valuable part of the policy toolkit, outreach to hard-to-reach populations will often need to include higher-touch interventions that simplify the underlying processes.

\section{Methods}

This paper encompasses six distinct but partially overlapping randomized controlled trials. The studies were implemented in spring 2018 (Studies 1 and 5) and spring 2019 (Studies 2, 3, 4, and 6), and focused on tax filing for the 2017 and 2018 tax years, respectively. United States income tax returns are typically filed between February and April, and are based on income received during the previous calendar year (the "tax year").

Interventions were delivered by public agencies, the California Franchise Tax Board and the California Department of Social Services, and by a non-governmental organization (Golden State Opportunity) that receives funding from the state to conduct EITC outreach. Some features were chosen to meet agency needs rather than those of researchers. ${ }^{3}$

\section{Sampling frames}

A major challenge for EITC outreach is that non-claimers are unlikely to appear in tax records, which are used for most tax-related outreach. Our samples of potential non-claimers drew from two sources. Studies 1-4 used a database purchased from a private marketing firm, TargetSmart. Records were purchased for California low income households, first in spring 2018 and then updated in spring 2019. This yielded approximately 1.3 million records.

From the original sample, we removed individuals younger than 18 , older than 70 , and those apparently living in group residences (identified by more than four records at the same address).

\footnotetext{
${ }^{2}$ While several of our treatment arms directed subjects to VITA sites that could assist with tax preparation, these may not have sufficiently lowered the barriers. Halpern-Meekin et al. (2015) report that EITC recipients experienced volunteer-based tax preparation services as untrustworthy and akin to government bureaucracies with "long lines in drab buildings, impersonal or even rude treatment, and the heavy atmosphere of desperate people soliciting aid", in contrast to the "bright," "neat," more professional for-profit tax preparers, who treat claimants "like a valued customer" (p. 83).

${ }^{3}$ Our analysis of the data from these experiments was overseen by the California State Committee for the Protection of Human Subjects (protocols 2019-021, 2019-002, 2018-037, 2018-194).
} 
Our eventual sample consisted of 1.2 million individuals in 1 million households.

Many of the individuals in studies 1-3 would have filed taxes even without being nudged. For Study 4, we focused on those households that had not filed taxes in the past three years. To do so, in early 2019 we merged the TargetSmart data to FTB tax filing records for tax years 20152017. This was a fuzzy merge, based on names, addresses, and dates of birth, with allowance for apparently legitimate differences between records in the two databases (e.g., misspelled names, alternative ways of recording addresses, potential local moves). The universe for Study 4 was limited to a subset of approximately 200,000 TargetSmart records that did not appear in the FTB filing records in any of the three preceding tax years.

The second original source of potential non-filers, used in Studies 5 and 6, was administrative records of participants in the CalFresh program, the California instantiation of the federal Supplemental Nutrition Assistance Program (SNAP). We began with approximately 6 million individuals enrolled in CalFresh at any point in calendar year 2017 (Study 5) or 2018 (Study 6), grouped into case (household) units. We excluded cases containing only seniors. We then linked adults to their quarterly earnings records for 2017:Q1 through 2017:Q3 for Study 5 and 2018:Q1 through 2018:Q3 for Study 6 from the California Employment Development Department, which administers the state's Unemployment Insurance program.

We used CalFresh case compositions and earnings records to simulate federal and CalEITC eligibility. Our simulations assumed that the CalFresh case corresponded to the potential tax household; that all children in the CalFresh case would qualify as children for purposes of EITC eligibility; that earnings in 2017:Q4 and 2018:Q4, which were not yet available when we administered treatments, would equal one-third of total earnings over the previous three quarters; and that there would be zero self employment earnings or other income not covered by the earnings records. Based on this simulation, we selected cases with EITC eligibility above $\$ 50$. This excluded those with zero or very low earnings and those with earnings too high to qualify for the EITC.

Last, we restricted to participating counties: Sacramento and San Diego in Study 5, and those counties plus San Francisco, San Mateo, and Santa Clara in Study 6. Welfare offices in these counties use text messages to communicate with CalFresh participants about their cases. We limited our sample to individuals with valid phone numbers who had consented to receiving these text messages.

The two data sources each have advantages and limitations. The TargetSmart sample provides a broad cross-section of low-income Californians, including those who interact with government infrequently. However, these data have limited information about earned income or family structure and may contain outdated or incorrect records. The CalFresh enrollee contact information is updated regularly, with detailed and reliable information about income and family composition. However, the CalFresh database only contains households already connected with state social assistance programs, meaning they have exhibited an awareness of and are willing to enroll in these 
forms of assistance.

\section{Randomization}

All six studies were implemented using stratified random assignment. Each included a control group that received no treatment and one or more treatment arms that received text messages or letters. Where there were multiple treatment arms, all were assigned with equal probability, though in several cases the control group was larger than any single treatment arm. Randomization was at the household level, defined by the address in the TargetSmart data and by the case number in the CalFresh data. A single representative was selected from each household to receive the treatment.

Appendix Table 2 provides details about sample sizes and randomization strata. Studies 1-4 were implemented sequentially, with assignment in one used as a stratification variable for the next, as discussed below. This ensured that treatments in each study were perfectly orthogonal to those in the other prior studies. Studies 1 and 2 used varying assignment rates across strata. In Study 1, assignment rates varied across counties and zip codes to meet GSO's needs. In Study 2, rates were set to yield 5,000 observations per treatment arm in Riverside county and 5,000 in the other counties combined. Other studies used constant assignment probabilities across strata.

\section{Procedures}

Treatments consisted of sending a single letter or a single text message to an individual chosen from each household. There was no other interaction with subjects. Control group members did not receive the letters or texts, though they may have been exposed to other outreach. Examples of each treatment can be found in the Appendix.

Study 1. Text messages were sent manually by GSO volunteers in March and April 2018, with observations sequenced randomly. Texts informed recipients of their potential eligibility and of the need to file a return in order to claim the credit, and included a link with more information to reduce learning costs. The exact wording of the texts varied over the course of the study.

Study 2. There were four treatment arms, delivered as different letters, that addressed learning costs and psychological costs related to potential mistrust of the messenger or message. Letters varied in two dimensions that both addressed source credibility: the source (GSO or FTB) and the formality. Each sender's letters used the relevant logos, signatures and return addresses. In addition, half were structured as formal letters and half as informal flyers. The front of each letter was printed in English; the back contained the same information in Spanish. Letters were mailed in February 2019.

Study 3. There were four treatment arms, each consisting of a single text message. To target learning costs, each message informed recipients about potential eligibility and the need to 
file taxes to claim the credit. Treatment arms 2 and 3 also targeted compliance costs by offering assistance through a hotline or via text respectively. Treatment arm 4 included additional information on the average benefit amount to further address learning costs. Texts were sent manually between February and April 2019.

Study 4. There were eight treatment arms, delivered as different letters. As noted above, inclusion in this study was conditioned on not having filed in any of the previous three years. Letters came from FTB and contained one of four different messages: a simple message about the credit; a simple message that also included information about the average value of the credit (addressing learning costs); a message that added information about the location, hours, and contact information of the nearest in-person free tax preparation assistance site (addressing compliance costs); and a message that included both the average value of the credit and tax assistance information. Each message was delivered in a formal and an informal version, with the idea that formal letters might signal more source credibility (addressing psychological costs). The front of each letter was printed in English; the back contained the same information in Spanish. In addition, each letter contained a URL at which recipients could find the letter translated into Korean, Vietnamese, Chinese, or Russian. Letters were mailed in February and March 2019. ${ }^{4}$

Study 5. All treated individuals received the same sequence of text messages, designed to address both learning and compliance barriers. The first message included a personalized benefit amount estimated using the recipients' household composition and quarterly earnings data (see the sampling frames subsection for more information). If the recipient texted " 1 " for more information, they were provided the URL to an online free tax-preparation software. If they responded "1" again, they were provided the address and hours of the closest VITA site to the client's 9 digit zip code. When that site required appointments, the text also included a link for registration. Texts were sent in English or Spanish, depending on the language indicated in the CalFresh record, and were delivered over two days in March 2018.

Study 6. There were three treatment arms, each delivered by text message. The first treatment arm was a simple text, informing recipients of their potential eligibility, and provided a URL to calculate their credit and a hotline to learn where to file for free. The second treatment arm provided the same information as the first text, along with the average benefit amount. The third treatment arm, as in Study 5, included a personalized credit amount. The three treatments did progressively more to address learning costs. Moreover, the fact that they came from the local CalFresh program should have increased source credibility and reduced psychological costs. Texts were delivered in March 2019 in the language indicated in the recipient's CalFresh record: English, Spanish, Chinese, or Vietnamese. Speakers of other languages received the English message.

\footnotetext{
${ }^{4}$ Seven of the eight treatment arms were mailed on February 15, 2019. Due to a mailroom error, letters for one arm (a formal letter with benefit amount and in-person free tax preparation site information) were not sent until March 25 , 2019.
} 
A design feature of all of our interventions is that they would all be easily scalable. The vast majority of nudge interventions run by governments at scale in the US are outreach efforts of this nature. A recent paper estimates that 30\% are physical letters, $20 \%$ are postcards, and almost $40 \%$ are emails (Dellavigna and Linos, 2020). Like our interventions, these outreach efforts may link to an in-person service, but directly nudging people in person occurs in less than $1 \%$ of cases.

In addition to being the nudge most commonly pursued by government, this type of informational intervention is also one studied by many scholars concerned about incomplete take-up of means-tested programs like the EITC. Several recent papers find that simply informing likely eligible individuals about the existence of a program with a single intervention can yield substantial effects on enrollment decisions (e.g., Bhargava and Manoli, 2015; Goldin et al., 2017; Armour, 2018; Barr and Turner, 2018; Finkelstein and Notowidigdo, 2019).

While our interventions themselves are low-cost, treatment arms in studies 3, 4, and 5 directed subjects to existing high-touch services, such as in-person assistance with tax returns. This is realistically what intensive interventions look like at scale - offers of help rather than forced provision. Finkelstein and Notowidigdo (2019) also study this type of enhanced intervention; their "compliance" treatment arm contained a phone number for a non-profit that would help seniors walk through their SNAP application. VITA sites offer a similar level of personalized assistance.

\section{Data and outcomes}

This study is made possible by unprecedented access to an array of administrative data from California, including income tax, wage, and social service records. Our use of social service and wage records is discussed above. We measure impacts of our interventions from actual California income tax filings.

For each study, we attempted to match each member of each household to FTB records, using the same fuzzy match discussed above. We measured whether each individual successfully matched to a California tax return and whether the return included a claim for either the federal EITC or CalEITC. Our primary outcome measures are an indicator for the presence of a matched return and an indicator for the presence of any EITC claim.

We analyze the data at the household level. We consider a household to have filed a return and to have taken up the EITC, respectively, if any member appears on a return and if any member's return includes an EITC claim.

We also track website visits in Studies 2, 4, and 6. Distinct URLs were used for each study and treatment arm. In Studies 2 and 4, we count all hits to these URLs; in Study 6, we count unique users. These measures are not available for the control groups.

Table 2 presents summary statistics for our main samples. The TargetSmart sample is relatively old, with a mean age of 60 , though nearly half are indicated as having children in the house. 
$55 \%$ are white, $58 \%$ are female, and $41 \%$ filed taxes in the previous year. In the CalFresh data, individuals are younger (mean age 37 ) and less likely to be white (23\%). A larger share have children, and $74 \%$ filed taxes in the prior year. In our CalFresh sample, we also have access to earnings records covering three quarters of the tax year, which we use to simulate EITC eligibility. We include in the study only families eligible for a federal or state EITC of at least $\$ 50$. In our sample, the average family's estimated annual income is just over $\$ 14,000$, and the average total (federal and state) EITC eligibility is $\$ 2,715$. Across all observable characteristics to which we have access, our trial arms are balanced.

\section{Statistical analysis}

Our primary analyses examine the effect of any treatment versus control. We construct a single observation for each simulated tax filing unit (household), and estimate regressions of the form:

$$
Y_{i s}=\alpha+T_{i s} \beta+\mu_{s}+\varepsilon_{i s}
$$

Here, $Y_{i s}$ is the outcome for household $i$ in stratum $s$ - either the presence of a tax return for some member of the household or the presence of an EITC claim. $T_{i s}$ is an indicator for treatment, and $\mu_{s}$ is a vector of stratum fixed effects. The impact of treatment is $\beta$. These are reported as the first estimates for each study (in black) in Figure 3.

A second set of analyses examine the effect of each treatment arm separately, where relevant. These are similar, but replace the single treatment effect with a series of separate effects:

$$
Y_{i s}=\alpha+\sum_{j} T_{i s j} \beta_{j}+\mu_{s}+\varepsilon_{i s}
$$

Here, $T_{i s j}$ an indicator for assignment to treatment arm $j$, and $\beta_{j}$ is the impact of that treatment relative to control. These are reported as the second and subsequent estimates for each study in Figure 3. P-values correspond to the hypotheses that each of the $\beta_{j}$ s, considered individually, equal zero. We have also tested the joint hypotheses that all of the $\beta_{j} \mathrm{~s}$ in a particular study equal zero. Across the four studies for which this is relevant and for both outcomes, we never reject the null hypothesis.

We also use a version of this model to test for baseline balance. For each baseline covariate, we estimate Equation 2 separately for each study and report $\beta_{j} \mathrm{~s}$ and the p-values for the joint hypotheses that all $\beta_{j}$ s equal zero in Appendix Tables 4-9. In Appendix Table 1, we report a single p-value that aggregates across all studies (1-4 in Panel A and 5-6 in Panel B). This is based on a sample that stacks all observations from the relevant group of studies and includes studyby-stratum and study-by-treatment-arm effects. The p-value is based on an F-test of the joint hypothesis that all study-by-treatment-arm effects equal zero. 
Last, in Studies 2 and 4, treatment arms were identified by the presence or absence of particular features. We estimate a separate set of models that examines the impact of each feature.

In Study 2, these take the form:

$$
Y_{i s}=\alpha+\text { Formal }_{i s} \gamma_{F}+F T B_{i s} \gamma_{M}+\mu_{s}+\varepsilon_{i s}
$$

where Formal $_{\text {is }}$ and $F T B_{\text {is }}$ are indicators for whether the letter was more formal (vs. informal) and came from the FTB (vs. GSO).

In Study 4, these take the form:

$$
Y_{i s}=\alpha+\text { Formal }_{i s} \gamma_{F}+\text { Amount }_{i s} \gamma_{A}+V I T A_{i s} \gamma_{V}+\mu_{s}+\varepsilon_{i s}
$$

where Formal $_{i s}$, Amount $_{i s}$, and VIT $A_{\text {is }}$ are indicators for the presence of formal, credit amount, and VITA information features on the letters. Estimates for Equations 3 and 4 are reported in Table 3.

\section{Results}

Figure 2 presents the main findings for two types of engagement indicators. In Studies 2 and 4, paper letters included URLs unique to each treatment arm, which allowed us to measure total website visits by each arm. In Study 6, we measure unique click-throughs to URLs embedded in the text messages. Our engagement measures capture only those who click on (or type in) the links included in our messages. We are unable to capture whether our treatments led recipients either to obtain more information via other means (e.g., internet searches for the EITC, CalEITC, or VITA, or other related terms) or to call a VITA site or the 211 number provided in many of our treatments. Thus, they likely understate the number of recipients who received and read our communications. Nevertheless, engagement is high compared to other estimates of successful online engagement: The average click through rate for our text messages was $10 \%$. Even letters, which required users to type URLs by hand, generated click through rates of around $1 \%{ }^{5}$

Engagement patterns are in line with our main hypotheses: Engagement was higher when the messenger was the government (and therefore perhaps better known); when the message provided useful, personalized, new information (i.e. the location of a VITA site or a personalized credit amount), and when more formal presentation was used to increase source credibility. In the Study 6 text messages, more information about the value of the credit increased engagement (messages including a personalized credit amount exhibited the highest engagement), but letters

\footnotetext{
${ }^{5}$ Irvine (2020) reports that click-through-rates (CTRs) for Facebook ads, the behavioral measure most similar to clicking on an unsolicited text message, are around 1\%, while a study by Wozney et al. (2019) obtains a CTR around $0.1 \%$.
} 
in Study 4 that listed the average credit amount did not elicit more pageviews.

Figure 3 presents our main findings regarding effects on tax filing and EITC claiming. We present the estimated effect of any treatment relative to control for each study, then for each separate treatment arm. Across all trials and each treatment arm, our interventions did not have significant effects on either outcome. Point estimates are uniformly close to zero. Because our sample sizes are large, our estimates are highly precise. In Studies 1, 3, and 4, we can rule out effects of 0.5 percentage point or larger; in the smaller studies, we can rule out effects larger than 1 or 1.5 percentage point.

Studies 2 and 4 were cross-classified to enable us to examine the effects of different features in isolation. We present estimated effects of letter features in Table 3: a formal letter format vs. a flyer; a credible messenger (the FTB) vs. an unknown NGO; the inclusion vs. omission of the average value of the credit; and information about the closest VITA site vs. none. As explained above, these features were designed to test particular hypothesized costs. The format and messenger features were meant to reduce psychological costs by increasing credibility. Specifying the credit's value should have reduced learning costs. Finally, VITA information should have reduced compliance costs. We find no evidence that any feature generated non-zero effects.

\section{Discussion}

As has been reinforced by the substantial challenges governments have faced in delivering economic relief during the COVID-19 crisis, the difficulty of accessing public benefits can be a major limitation to the effectiveness of government policy. Yet, it remains unclear whether the low takeup rates for many public programs reflect design choices, lack of awareness, or other factors. In the absence of good understanding of the determinants of take-up, many efforts to increase take-up begin and end with low-cost informational interventions, sometimes called "nudges."

Early successes demonstrated that these interventions can yield significant effects on enrollment decisions (Thaler and Sunstein, 2009; Hummel and Maedche, 2019; Allcott, 2016; Gerber and Rogers, 2009; Beshears et al., 2015). These successes led to the creation of over 200 "nudge units" working in and with governments across the world (OECD, 2017). However, our understanding of what types of nudges work, in what settings, and for whom remains underdeveloped. Most public nudges focus on people who are already interacting with government programs. This makes intuitive sense: It is both practically and theoretically easier to conduct effective outreach to individuals who already have relationships with the government agency providing the nudge. Understanding how to reach people who have not had previous interactions with government is crucial to improving equity in government service delivery and helping the most vulnerable populations escape poverty. This study aimed to do just that. Based on extant theories about behavioral reasons for non-take-up of benefit programs, our messages should have raised partici- 
pation.

Similar to many behavioral studies, our experiments show substantial engagement, measured by click-throughs or visits to a website. These show expected patterns, indicating that messages were received and that many recipients engaged with the material they received. Yet all of our messages had null effects on the intended behavioral outcomes, filing taxes and claiming the EITC. Our sample sizes are large enough and the effect sizes small and consistent enough that we are confident that our results can be interpreted as precise zeros.

There are several potential explanations for the failure of our outreach efforts.

First, it is possible that the recipients of our messages were already exposed to the relevant information, and that outreach would have been effective in previous years or in other contexts where there are fewer additional outreach efforts. As with any randomized controlled trial, we cannot make strong claims about external validity.

Second, the value of the EITC may not be large enough to warrant filing a return and claiming it. Non-filers in our sample are eligible for smaller credits than are filers, on average (see Appendix Figures 3 and 4). Twenty-five percent of non-filers are eligible for credits of $\$ 300$ or less, as compared with $9 \%$ of filers. For most non-filers, however, potential credits are large relative to plausible financial costs. Three-quarters of non-filers are eligible for credits in excess of $\$ 300$ - enough to outweigh the potential financial costs of paying a tax preparer to file returns (U.S. Government Accountability Office 2014, National Society of Accountants n.d.).

Third, our messages - one-time communications that inform low-income households that they are eligible for large sums of cash - may simply feel too good to be true. We tested various message framings that aimed to get past this resistance, varying formatting of the messages and their sources to increase credibility. Nevertheless, it is possible that none of these broke through, but that alternative messages or messengers would be more successful.

Fourth, the particular messages that we sent may have been ineffective, where others would have been more effective. For example, perhaps messages sent earlier in the tax season, or repeated contacts, would have yielded different results. These are potential lines for future inquiry. However, we do not think these are strong candidates for explanations. Our design choices were grounded in behavioral theories drawn from the literature on administrative burden and barriers to take-up, and our various treatments spanned a wide range of potential messages. While it remains possible that we missed the one specific message that would have been effective, this seems unlikely. More plausible is that repeated contacts would have been more effective, but we note that a number of successful interventions in the literature (e.g., Bhargava and Manoli, 2015; Finkelstein and Notowidigdo, 2019) are also based on a single outreach message.

Moreover, our treatments are similar to those that are commonly used in practice. Our partners routinely use one-time, low-cost, low-touch informational campaigns, through targeted text messages, letters, or postcards, to communicate with their clients about benefits and programs. These 
organizations know that not every recipient interacts with their outreach - but do expect that even if a small percentage take action, the total benefits received for this small group justify the cost of outreach at scale. Our results indicate that this logic may be flawed, as we cannot count on even small effects from this type of outreach. Moving behavior seems to require a larger investment.

Fifth, some eligible filers may face additional direct or psychological costs to interacting with the federal tax agency that may not be addressed simply through information. For example, a family concerned that immigration authorities would use tax returns or claiming behavior to target enforcement efforts or deny citizenship applications might be willing to leave free money on the table. Our interventions were carried out in 2018 and 2019, when such mistrust may have been heightened.

Finally, our treatments do not directly reduce compliance or psychological costs. Instead, we test the effect of messages that use information to reduce perceived learning, compliance and psychological costs. Our evidence suggests that nudges alone may be insufficient, but does not indicate that such costs are absent. The real compliance costs faced by our target population may simply be too high for our messages to overcome. While some trial arms pointed recipients to phone and online support as well as free tax filing assistance, actually receiving that help would have involved seeking out that assistance, going to a VITA site at specified times, compiling all of the required documents, and potentially making an advance appointment. Expanding the availability of this type of free tax support by extending the hours and availability of VITA sites, by increasing access to and quality of free online resources, or by bundling tax services with other services for low-income families may be crucial in helping people overcome real compliance hurdles. Similarly, simplifying the tax filing process itself by using existing administrative data to pre-fill tax returns could reduce real compliance costs.

A first step in understanding the nature of these costs for those who may have limited positive interactions with government is to use linkages of existing data, as we have, to identify potentially eligible households. More research on familiarity with tax filing and awareness of the EITC among non-filers, as well as more qualitative research on the psychological and compliance costs these households face in claiming the credit, would help inform future evaluations of higher-touch interventions that might be able to overcome those costs.

Nudges can provide a low-cost way to achieve many public purposes. They are particularly well suited to bringing marginal people over the threshold into participation, but are less likely to be successful for more inframarginal potential participants. For these populations, higher-touch interventions, particularly design choices that make programs accessible from the beginning, are likely to be required. 


\section{References}

Allcott, H. (2016). Paternalism and energy efficiency: an overview. Annual Review of Economics, 8:145-176.

Armour, P. (2018). The role of information in disability insurance application: An analysis of the social security statement phase-in. American Economic Journal: Economic Policy, 10(3):1-41.

Barr, A. and Turner, S. (2018). A letter and encouragement: Does information increase postsecondary enrollment of ui recipients? American Economic Journal: Economic Policy, 10(3):42-68.

Beecroft, E. (2012). EITC take-up by recipients of public assistance in Virginia and results of a low-cost experiment to increase EITC claims. Unpublished manuscript.

Benartzi, S., Beshears, J., Milkman, K. L., Sunstein, C. R., Thaler, R. H., Shankar, M., Tucker-Ray, W., Congdon, W. J., and Galing, S. (2017). Should governments invest more in nudging? Psychological Science, 28(8):1041-1055.

Bergman, P., Denning, J. T., and Manoli, D. (2019). Is information enough? the effect of information about education tax benefits on student outcomes. Journal of Policy Analysis and Management, 38(3):706-731.

Beshears, J., Choi, J. J., Laibson, D., Madrian, B. C., and Milkman, K. L. (2015). The effect of providing peer information on retirement savings decisions. The Journal of Finance, 70(3):11611201.

Bettinger, E. P., Long, B. T., Oreopoulos, P., and Sanbonmatsu, L. (2012). The role of application assistance and information in college decisions: Results from the H\&R Block FAFSA experiment. The Quarterly Journal of Economics, 127(3):1205-1242.

Bhargava, S. and Manoli, D. (2015). Psychological frictions and the incomplete take-up of social benefits: Evidence from an IRS field experiment. American Economic Review, 105(11):3489-3529.

Bird, K. A., Castleman, B. L., Denning, J. T., Goodman, J., Lamberton, C., and Rosinger, K. O. (2019). Nudging at scale: Experimental evidence from FAFSA completion campaigns. NBER Working Paper.

Blumenthal, M., Erard, B., and Ho, C.-C. (2005). Participation and compliance with the earned income tax credit. National Tax Journal, pages 189-213.

Camerer, C. F., Dreber, A., Holzmeister, F., Ho, T.-H., Huber, J., Johannesson, M., Kirchler, M., Nave, G., Nosek, B. A., Pfeiffer, T., et al. (2018). Evaluating the replicability of social science 
experiments in nature and science between 2010 and 2015. Nature Human Behaviour, 2(9):637644.

Castleman, B. L., Patterson, R., and Skimmyhorn, W. (2019). Benefits left on the table: Evidence from the Servicemembers' Civil Relief Act. Economics of Education Review.

Chetty, R., Friedman, J. N., and Saez, E. (2013). Using differences in knowledge across neighborhoods to uncover the impacts of the EITC on earnings. American Economic Review, 103(7):26832721.

Cranor, T., Kotb, S., and Goldin, J. (2019). Does informing employees about tax benefits increase take-up?: Evidence from EITC notification laws. National Tax Journal, 72(2):1-8.

Currie, J. (2006). The take-up of social benefits. In Alan Auerbach, D. C. and Quigley, J., editors, Poverty, the Distribution of Income, and Public Policy, pages 80-148. Russell Sage.

Dellavigna, S. and Linos, E. (2020). RCTs to scale: Comprehensive evidence from two nudge units.

Finkelstein, A. and Notowidigdo, M. J. (2019). Take-up and targeting: Experimental evidence from SNAP. The Quarterly Journal of Economics, 134(3):1505-1556.

Gerber, A. S. and Rogers, T. (2009). Descriptive social norms and motivation to vote: Everybody's voting and so should you. The Journal of Politics, 71(1):178-191.

Goldin, J., Homonoff, T., and Tucker-Ray, W. (2017). Retirement contribution rate nudges and plan participation: Evidence from a field experiment. American Economic Review, 107(5):456-61.

Goldin, J. and Liscow, Z. (2018). Tax benefit complexity and take-up: Lessons from the earned income tax credit. Tax Law Review, 72.

Guyton, J., Langetieg, P., Manoli, D., Payne, M., Schafer, B., and Sebastiani, M. (2017). Reminders and recidivism: using administrative data to characterize nonfilers and conduct EITC outreach. American Economic Review: Papers E Proceedings, 107(5):471-75.

Hallsworth, M., List, J. A., Metcalfe, R. D., and Vlaev, I. (2017). The behavioralist as tax collector: Using natural field experiments to enhance tax compliance. Journal of Public Economics, 148:1431.

Halpern-Meekin, S., Edin, K., Tach, L., and Sykes, J. (2015). It's not like I'm poor: How working families make ends meet in a post-welfare world. Univ of California Press.

Herd, P. and Moynihan, D. P. (2019). Administrative burden: Policymaking by other means. Russell Sage Foundation. 
Hotard, M., Lawrence, D., Laitin, D. D., and Hainmueller, J. (2019). A low-cost information nudge increases citizenship application rates among low-income immigrants. Nature Human Behaviour, 3(7):678-683.

Hovland, C. I. and Weiss, W. (1951). The influence of source credibility on communication effectiveness. Public Opinion Quarterly, 15(4):635-650.

Hoynes, H. and Rothstein, J. (2016). Tax policy toward low-income families. NBER Working Paper.

Hummel, D. and Maedche, A. (2019). How effective is nudging? a quantitative review on the effect sizes and limits of empirical nudging studies. Journal of Behavioral and Experimental Economics, 80:47-58.

IRS (n.d.). EITC participation rates by state. https://www.eitc.irs.gov/eitc-central/ participation-rate/eitc-participation-rate-by-states. Accessed: 2020-03-20.

Irvine, M. (2020). Facebook ad benchmarks for your industry. https://www . wordstream . $\mathrm{com} / \mathrm{blog} / \mathrm{ws} / 2017 / 02 / 28 /$ facebook-advertising-benchmarks. Accessed: 2020-0320.

Iselin, J., Lacoe, J., Rothstein, J., and Unrath, M. (2020). Take-up of the federal and California EITC: Measuring participation with administrative data. Technical report, California Policy Lab.

Jones, M. R. (2014). Changes in EITC eligibility and participation, 2005-2009. Center for Administrative Records Research and Applications Working Paper.

Kopczuk, W. and Pop-Eleches, C. (2007). Electronic filing, tax preparers and participation in the earned income tax credit. Journal of Public Economics, 91(7-8):1351-1367.

Madrian, B. C. and Shea, D. F. (2001). The power of suggestion: Inertia in 401 (k) participation and savings behavior. The Quarterly Journal of Economics, 116(4):1149-1187.

Meiselman, B. S. (2018). Ghostbusting in Detroit: Evidence on nonfilers from a controlled field experiment. Journal of Public Economics, 158:180-193.

Moffitt, R. et al. (1983). An economic model of welfare stigma. American Economic Review, 73(5):1023-1035.

Nichols, A. and Rothstein, J. (2016). The earned income tax credit. In Economics of Means-Tested Transfer Programs in the United States, Volume 1, pages 137-218. University of Chicago Press.

OECD (2017). Behavioural insights and public policy: Lessons from around the world. OECD. 
Phillips, K. R. (2001). Who knows about the earned income tax credit? Technical report, The Urban Institute.

Plueger, D. (2009). The EITC participation rate for tax year 2005. Internal Revenue Service Bulletin.

Pornpitakpan, C. (2004). The persuasiveness of source credibility: A critical review of five decades' evidence. Journal of Applied Social Psychology, 34(2):243-281.

Smeeding, T. M., Phillips, K. R., and O'Connor, M. (2000). The EITC: Expectation, knowledge, use, and economic and social mobility. National Tax Journal, pages 1187-1209.

Thaler, R. H. and Benartzi, S. (2004). Save more tomorrow ${ }^{\mathrm{TM}}$ : Using behavioral economics to increase employee saving. Journal of Political Economy, 112(S1):S164-S187.

Thaler, R. H. and Sunstein, C. R. (2009). Nudge: Improving decisions about health, wealth, and happiness. Penguin.

Wozney, L., Turner, K., Rose-Davis, B., and McGrath, P. J. (2019). Facebook ads to the rescue? recruiting a hard to reach population into an internet-based behavioral health intervention trial. Internet interventions, 17:100246. 


\section{Figures}

Figure 1: Federal and California EITC schedules for a single-parent family with two children, tax year 2018

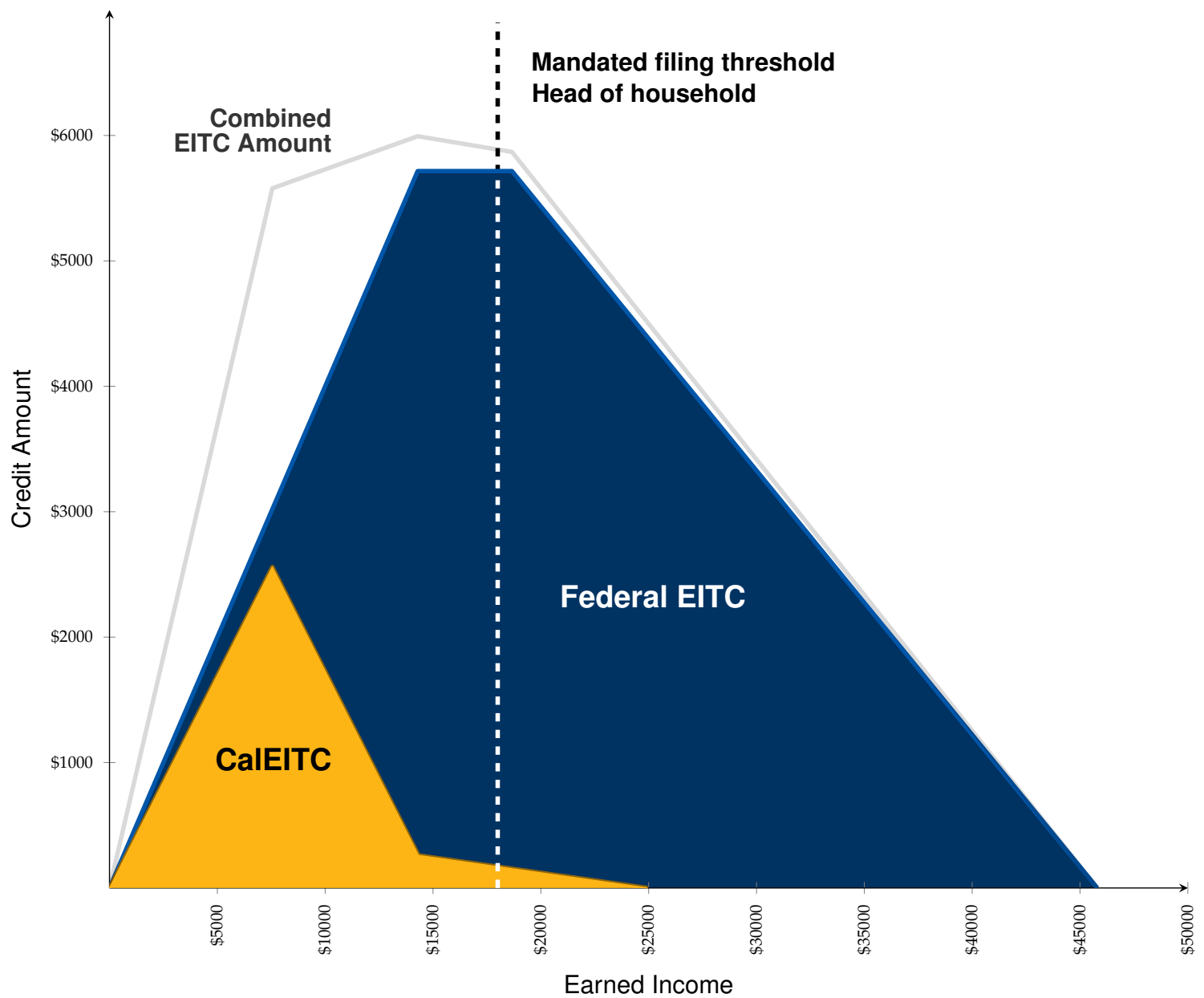

Notes. This diagram illustrates the federal (blue) and state (gold) EITC schedules for a head of household with two children. The gray line illustrates the combined value of the EITC for a filer who claims both credits. The dotted line denotes the filing threshold for a head of household in tax year 2018, which was $\$ 18,000$; families with incomes below this threshold are generally not required to file returns. 
Figure 2: Web traffic by pooled treatment features, tax year 2018

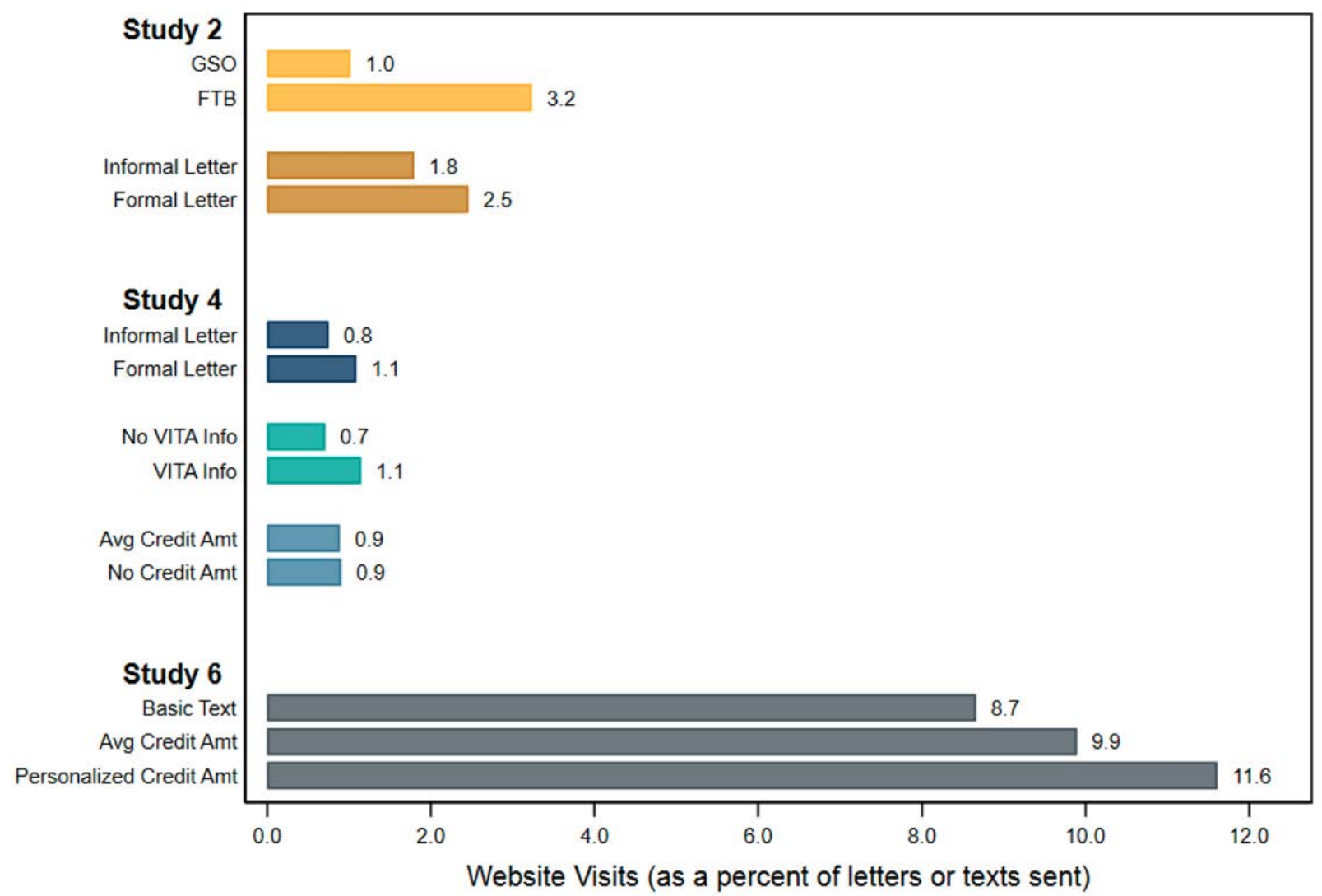

Notes. Figure shows measures of engagement as a share of the number of messages sent, by study and treatment feature. In Studies 2 and 4, the features are shared across several treatment arms, and traffic estimates aggregate over all relevant arms. In Studies 3 and 4, engagement measure is visits to a website, hand-entered from treatment-armspecific URLs included in letters, divided by the number of letters sent. In Study 6, engagement measure is the number of unique visitors to a URL included in the text messages, divided by the number of texts sent. 
Figure 3: Effects of outreach treatments on tax filing and EITC claiming, by study

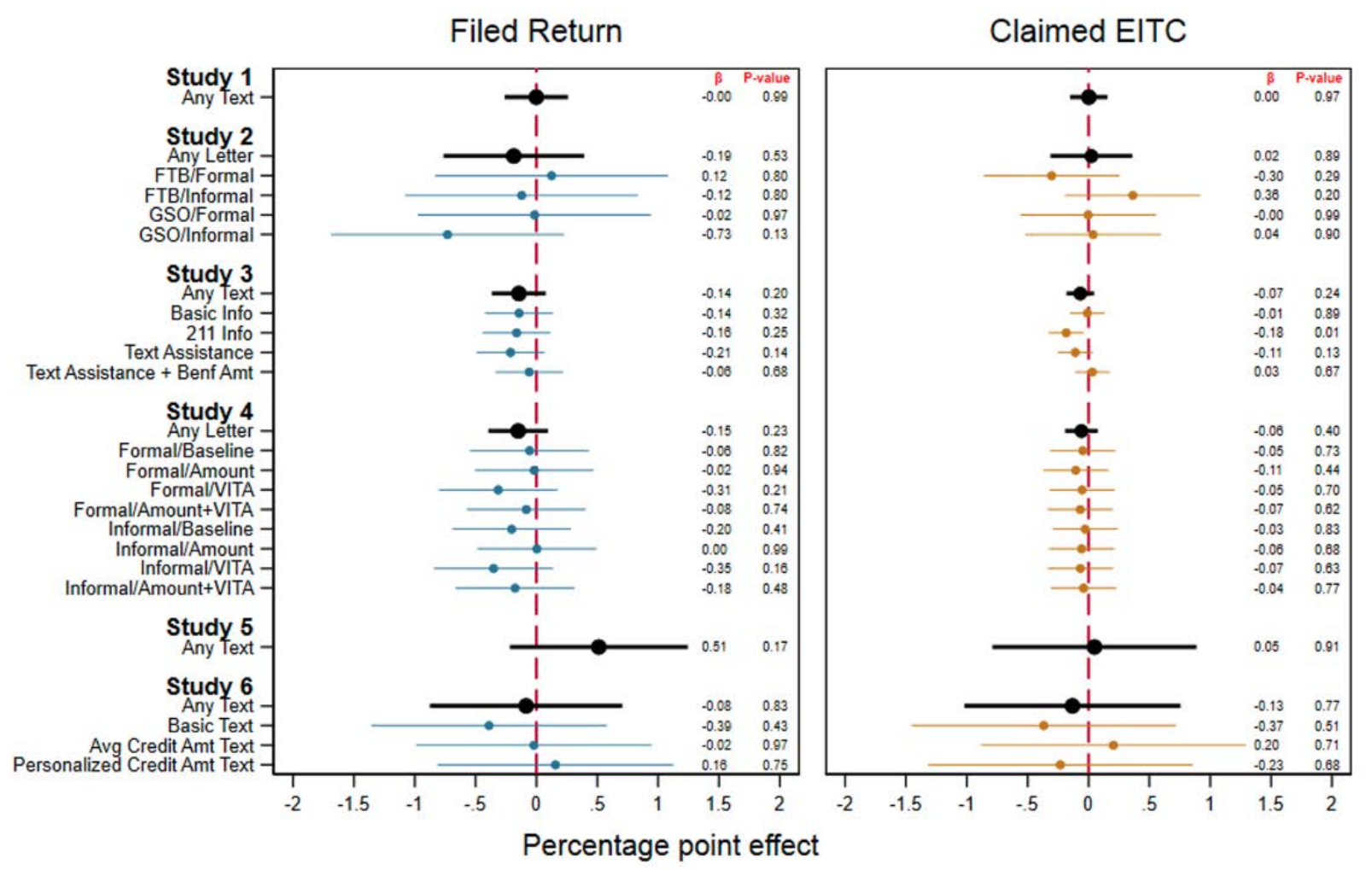

Notes. Figure shows estimated treatment effects on tax filing (left) and EITC claiming (right), with 95\% confidence intervals. P-values reflect two-sided significant tests. Larger black dots and lines show effects of any treatment vs. control, while smaller, colored dots and lines show effects of each treatment arm individually. 


\section{Tables}

Table 1: Study descriptions

\begin{tabular}{|c|c|c|c|}
\hline Study & $\begin{array}{l}\text { Treatment } \\
\text { arms }\end{array}$ & Treatment mode & Costs addressed \\
\hline $\begin{array}{l}\text { Study } 1 \\
\mathrm{~N}=639,244\end{array}$ & 1 & $\begin{array}{l}\text { Text messages sent by } \\
\text { NGO }\end{array}$ & $\begin{array}{l}\text { Learning } \\
\bullet \text { Simple message }\end{array}$ \\
\hline $\begin{array}{l}\text { Study } 2 \\
N=96,370\end{array}$ & 4 & $\begin{array}{l}\text { Letters sent by state } \\
\text { government and NGO }\end{array}$ & $\begin{array}{l}\text { Learning } \\
\text { - Simple message vs. average benefit amount } \\
\text { Psychological } \\
\text { • Government vs. NGO messenger } \\
\text { - Formal vs. informal }\end{array}$ \\
\hline $\begin{array}{l}\text { Study } 3 \\
\mathrm{~N}=1,084,018\end{array}$ & 4 & $\begin{array}{l}\text { Text messages sent by } \\
\text { NGO }\end{array}$ & $\begin{array}{l}\text { Learning } \\
\text { •Simple message vs. average benefit amount } \\
\text { Compliance } \\
\text {-Web vs. text vs. phone-based assistance }\end{array}$ \\
\hline $\begin{array}{l}\text { Study } 4 \\
\mathrm{~N}=204,285\end{array}$ & 8 & $\begin{array}{l}\text { Letters sent by state } \\
\text { government }\end{array}$ & $\begin{array}{l}\text { Learning } \\
\text {-Simple message vs. average benefit amount } \\
\text { Compliance } \\
\text { - Local in-person free tax preparation information } \\
\text { Psychological } \\
\text { - Formal vs. informal formatting }\end{array}$ \\
\hline $\begin{array}{l}\text { Study } 5 \\
\mathrm{~N}=38,093\end{array}$ & 1 & $\begin{array}{l}\text { Text messages sent by } \\
\text { county welfare office }\end{array}$ & $\begin{array}{l}\text { Learning } \\
\text { - Personalized benefit amount } \\
\text { Compliance } \\
\text { • Free tax preparation website } \\
\text { - Address of local in-person free tax preparation assistance }\end{array}$ \\
\hline $\begin{array}{l}\text { Study } 6 \\
N=47,104\end{array}$ & 3 & $\begin{array}{l}\text { Text messages sent by } \\
\text { county welfare office }\end{array}$ & $\begin{array}{l}\text { Learning } \\
\text { • Average vs. personalized benefit amount }\end{array}$ \\
\hline
\end{tabular}


Table 2: Summary statistics and balance tests

\begin{tabular}{llll} 
& Mean & SD & P-value \\
\cline { 3 - 4 } Panel A: Target Smart data (N=1,084,018) & & & \\
\hline Age & 60 & 21 & 0.24 \\
Male & 0.42 & 0.49 & 0.14 \\
White & 0.55 & 0.50 & 0.20 \\
Married & 0.21 & 0.41 & 0.66 \\
Have children & 0.47 & 0.50 & 0.72 \\
College graduate & 0.22 & 0.42 & 0.53 \\
Filed in previous tax year & 0.41 & 0.49 & 0.49 \\
Filed in current year, prior to start of study & 0.11 & 0.31 & 0.83 \\
& & & \\
Panel B: CalFresh participants (N=47,104) & & & \\
Age & 37 & 12 & 0.14 \\
Male & 0.36 & 0.48 & 0.86 \\
White & 0.23 & 0.42 & 0.14 \\
Primary language is English & 0.75 & 0.43 & 0.74 \\
Presence of other adults & 0.31 & 0.46 & 0.18 \\
Presence of children & 0.68 & 0.47 & 1.00 \\
Filed in previous tax year & 0.74 & 0.44 & 0.53 \\
Filed in current year, prior to start of study & 0.43 & 0.49 & 0.39 \\
Predicted annual income & 14,178 & 10,636 & 0.72 \\
Predicted EITC amount & 2,715 & 2,176 & 0.69 \\
\hline \hline
\end{tabular}

Notes. Summary statistics are for samples used in Studies 2 and 6. The rightmost column shows p-value for a hypothesis test that the indicated characteristic has the same mean across all assignment arms in all relevant studies (1-4 in panel A; 5-6 in panel B). 
Table 3: Estimates of pooled treatment features, identified from across-treatment arm variation

\begin{tabular}{lccccc}
\hline \hline & \multicolumn{2}{c}{ Filed Return } & & \multicolumn{2}{c}{ Claimed EITC } \\
\cline { 2 - 3 } \cline { 5 - 6 } & Study 2 & Study 4 & & Study 2 & Study 4 \\
\hline Baseline & 0.377 & 0.089 & & 0.076 & 0.024 \\
& $(0.002)$ & $(0.001)$ & & $(0.001)$ & $(0.000)$ \\
Formal letter & 0.002 & -0.000 & -0.004 & -0.000 \\
& $(0.004)$ & $(0.001)$ & & $(0.005)$ & $(0.001)$ \\
Messenger: FTB & 0.000 & & 0.001 & \\
& $(0.004)$ & & $(0.002)$ & \\
Benefit amount & & 0.001 & & -0.000 \\
& & $(0.001)$ & & $(0.001)$ \\
VITA referral & & -0.002 & & -0.000 \\
& & $(0.001)$ & & $(0.001)$ \\
\hline $\mathrm{N}$ & 96,370 & 204,285 & 96,370 & 204,285 \\
p-value, $\gamma=0$ & 0.89 & 0.45 & 0.53 & 0.88 \\
\hline \hline
\end{tabular}

Notes. These estimates correspond to $\gamma$ coefficients in Equations 3 and 4. 


\title{
Can Nudges Increase Take-up of the EITC?: Evidence from Multiple Field Experiments
}

\author{
Appendix
}

Appendix Table 1 lists the assignment rates and stratification used in each study. Appendix Table 2 lists the minimum detectable effects stated in the pre-analysis plan for each study.

Appendix Tables 3-8 present full balance checks for each of the available baseline covariates and each treatment. There is one table for each study. In each, the first column shows the control group mean and standard deviation. The next series of columns, one for each treatment arm, shows the estimated difference between that treatment arm and the control group, along with standard errors. These are the $\beta_{j}$ coefficients from equation (2), using the baseline covariates as dependent variables. The final column of each table shows a p-value for the hypothesis that the means are the same in each treatment group as in the control; that is, that all of the $\beta_{j}$ s are jointly zero. Very few of the estimated $\beta_{j}$ s are statistically significant, evaluated individually, and all of the estimated effects are substantively small. None of our tests indicate joint significance for any study or covariate.

The final columns of Appendix Tables 3-8 present estimated treatment effects on our primary outcomes, tax filing and EITC claiming. These are again based on equation (2), and correspond to the individual treatment arm effects plotted in Figure 3.

Appendix Figures 1 and 2 use the CalFresh data from Study 6 to simulate annual incomes and EITC credit eligibility for each family in our sample. We plot the histograms of those two measures, separately for the subsets of the control group who do and do not file tax returns. These figures indicate that filers have much higher incomes and higher credit eligibility than non-filers, on average. Twenty-five percent of non-filers are eligible for credits of $\$ 300$ or less, as compared with $9 \%$ of filers. Nevertheless, $75 \%$ of non-filers are eligible for credits in excess of $\$ 300$ - enough to outweigh the potential financial costs of paying a tax preparer to file returns (U.S. Government Accountability Office 2014, National Society of Accountants n.d.).

The various treatment letters and text messages are reproduced in Appendix Figures 3-18. 


\section{Appendix figures and tables}

Appendix Table 1: Randomization details by study

\begin{tabular}{|c|c|c|c|c|}
\hline Study & $\begin{array}{l}\text { Treatment } \\
\text { arms }\end{array}$ & $\begin{array}{l}\mathrm{N} \\
\text { (households) }\end{array}$ & $\begin{array}{l}\text { Assignment frequencies / } \\
\text { proportions }\end{array}$ & Strata \\
\hline 1 & 1 & 639,244 & $\begin{array}{l}200,000 \text { control; remainder } \\
\text { treatment }\end{array}$ & $\begin{array}{l}\text { Zip code, dummies for } \\
\text { white/nonwhite and } \\
\text { college/non-college }\end{array}$ \\
\hline 2 & 4 & 96,370 & $\begin{array}{l}10,000 \text { to each treatment } \\
\text { arm; remainder control }\end{array}$ & $\begin{array}{l}\text { County, zip code, missing DOB, } \\
\text { Study } 1 \text { assignment }\end{array}$ \\
\hline 3 & 4 & $1,084,018$ & $\begin{array}{l}20 \% \text { to each treatment arm; } \\
20 \% \text { control }\end{array}$ & $\begin{array}{l}\text { County, zip code, missing DOB, } \\
\text { Study } 1 \text { and Study } 2 \text { assignment }\end{array}$ \\
\hline 4 & 8 & 204,285 & $\begin{array}{l}15,000 \text { to each treatment } \\
\text { group; remainder control }\end{array}$ & $\begin{array}{l}\text { County, zip code, Study } 1 \\
\text { assignment and Study } 3 \text { assignment }\end{array}$ \\
\hline 5 & 1 & 38,093 & $50 \%$ treatment; $50 \%$ control & $\begin{array}{l}\text { County, race, single adult, four bins } \\
\text { of income, presence of children }\end{array}$ \\
\hline 6 & 3 & 47,104 & $\begin{array}{l}25 \% \text { to each treatment arm; } \\
25 \% \text { control }\end{array}$ & $\begin{array}{l}\text { County, presence of children, low or } \\
\text { moderate income, primary } \\
\text { language }\end{array}$ \\
\hline
\end{tabular}

Notes. Study 1 used the TargetSmart records updated through spring 2018, and excluded those older than 70 . Studies 2 and 3 included older individuals and those added in the 2019 update. Study 2 limited to a subset of records in six counties (Alameda, Contra Costa, Marin, Riverside, San Francisco, San Mateo, and Santa Clara). For Studies 1-4, some zip codes contained too few observations to assign observations to treatment and control with nearly equal probabilities. We grouped observations in these less populous zip codes to a simulated county-level "zip code", and used this simulated zip code for stratification. For Study 5, we stratified on four income bins: $\$ 0$ to $\$ 5000, \$ 5000$ to $\$ 11,500$, $\$ 11,500$ to $\$ 20,000$ and $\$ 20,000$ to $\$ 50,000$. The race variable used for stratification had four values: White, Latinx, Black/Asian/PI/American Indian/Alaskan Native. The indicator for single adult reflected whether we identified the case as having one working-age adult or more than one working-age adult. For Study 6, we stratified on two broader income bins: $\$ 0$ to $\$ 12,500$ and $\$ 12,500$ to $\$ 55,000$; primary languages were the four languages in which we distributed the messages, English, Chinese, Spanish, and Vietnamese. 
Appendix Table 2: Pre-registration minimum detectable effect estimates

\begin{tabular}{llll}
\hline \hline Study & OSF ID & $\begin{array}{l}\text { MDE } \\
\text { Any treatment vs. control }\end{array}$ & $\begin{array}{l}\text { MDE } \\
\text { Individual treatment arm vs. control }\end{array}$ \\
\hline 1 & https://osf.io/ct58w & 0.3 percentage point & $\mathrm{n} / \mathrm{a}$ \\
2 & https://osf.io/z8ebc & $0.8 \mathrm{pp}$ & $1.4 \mathrm{pp}$ \\
3 & https://osf.io/z8ebc & $0.3 \mathrm{pp}$ & $0.4 \mathrm{pp}$ \\
4 & https://osf.io/z8ebc & $0.6 \mathrm{pp}$ & $1.1 \mathrm{pp}$ \\
5 & https://osf.io/msh7t & $1.6 \mathrm{pp}$ & $\mathrm{n} / \mathrm{a}$ \\
6 & https://osf.io/p2q4y & $1.4 \mathrm{pp}$ & $1.7 \mathrm{pp}$ \\
\hline \hline
\end{tabular}

Notes. The pre-analysis plan for study 5 was posted before the eventual sample size was known, and does not contain a power calculation. We estimate this MDE in the same way that we estimated the MDE for Study 6, as described in that study's posted pre-analysis plan. Studies 2-4 are all described in the same pre-analysis plan. We used different numbers to identify those experiments than we do here. Study 3 corresponds to what we called in the pre-analysis plan Experiment 1, Study 4 corresponds to Experiment 2, and Study 2 corresponds to Experiment 3. 
Appendix Table 3: Differences in subjects' characteristics, filing rate and EITC claiming rate by treatment assignment in Study 1

\begin{tabular}{|c|c|c|c|}
\hline & $\begin{array}{c}\text { Control Group } \\
\text { Average } \\
(\text { mean/sd })\end{array}$ & Basic Text & $\begin{array}{l}\text { P-value from } \\
\text { F-test: } \beta=0\end{array}$ \\
\hline \multicolumn{4}{|c|}{ Baseline Characteristics } \\
\hline Age & $\begin{array}{c}47.219 \\
{[13.651]}\end{array}$ & $\begin{array}{c}0.037 \\
(0.045)\end{array}$ & 0.407 \\
\hline Male & $\begin{array}{c}0.425 \\
{[0.494]}\end{array}$ & $\begin{array}{l}-0.000 \\
(0.002)\end{array}$ & 0.896 \\
\hline White & $\begin{array}{c}0.444 \\
{[0.497]}\end{array}$ & $\begin{array}{l}-0.000 \\
(0.000)\end{array}$ & 0.732 \\
\hline Married & $\begin{array}{c}0.187 \\
{[0.390]}\end{array}$ & $\begin{array}{c}-0.001 \\
(0.001)\end{array}$ & 0.505 \\
\hline Have Children & $\begin{array}{c}0.582 \\
{[0.493]}\end{array}$ & $\begin{array}{c}0.001 \\
(0.002)\end{array}$ & 0.691 \\
\hline College Grad & $\begin{array}{c}0.386 \\
{[0.487]}\end{array}$ & $\begin{array}{l}-0.002 \\
(0.001)\end{array}$ & 0.063 \\
\hline Filed Early & $\begin{array}{c}0.219 \\
{[0.414]}\end{array}$ & $\begin{array}{l}-0.001 \\
(0.001)\end{array}$ & 0.393 \\
\hline \multicolumn{4}{|c|}{ Treatment Effects } \\
\hline Filed Return & $\begin{array}{c}0.405 \\
{[0.491]}\end{array}$ & $\begin{array}{l}-0.000 \\
(0.001)\end{array}$ & 0.770 \\
\hline Claimed EITC & $\begin{array}{c}0.085 \\
{[0.279]}\end{array}$ & $\begin{array}{c}0.000 \\
(0.001)\end{array}$ & 0.908 \\
\hline $\mathrm{N}$ & 195,200 & 444,044 & \\
\hline
\end{tabular}

Notes. Standard errors in parentheses; standard deviations in square brackets. Asterisks indicate statistical significance of individual coefficients; ${ }^{*}=10 \%,{ }^{* *}=5 \%,{ }^{* * *}=1 \%$. The $p$-values in the final column are for tests of the hypothesis that the treatment effect on the indicated characteristic or outcome is zero. 


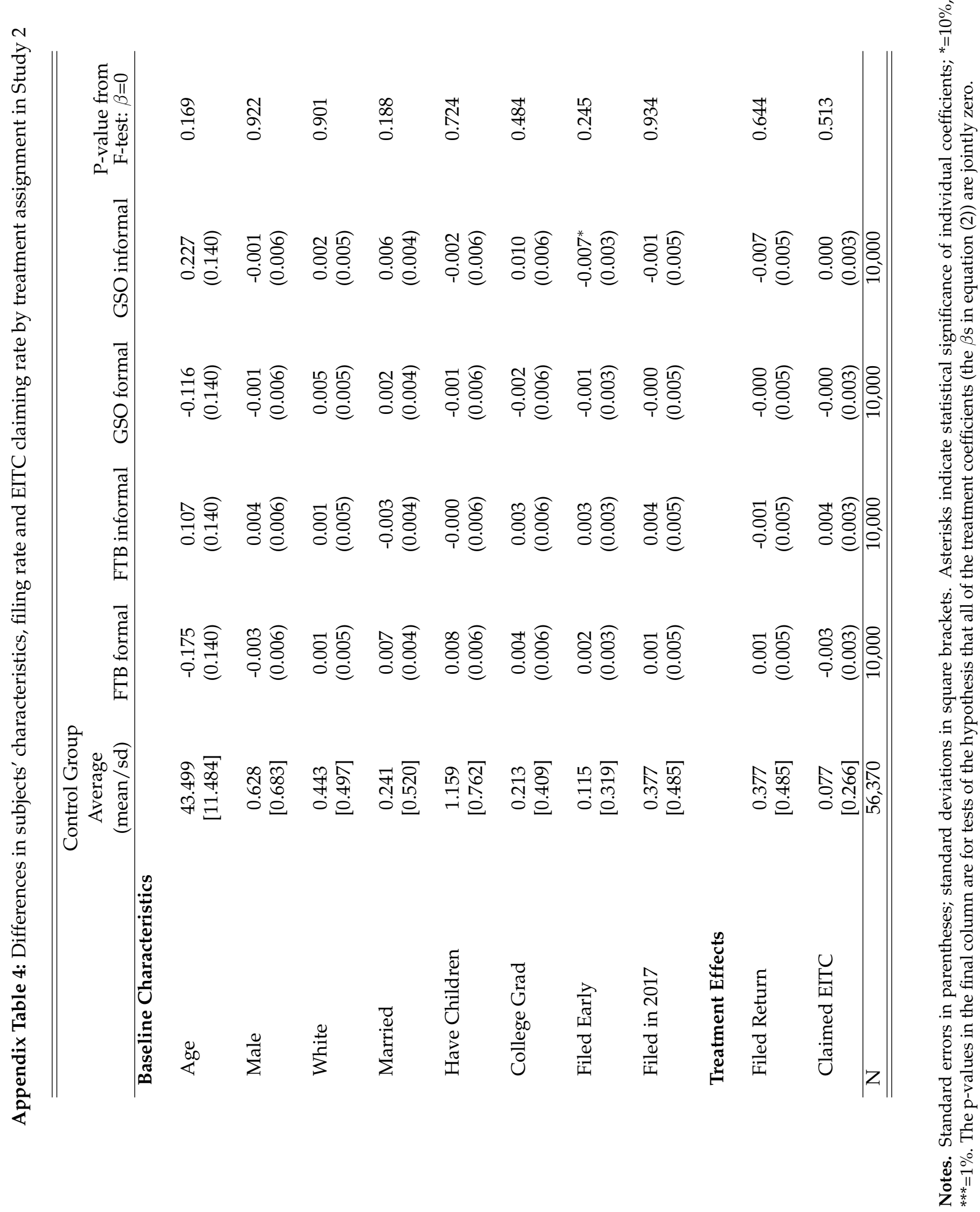




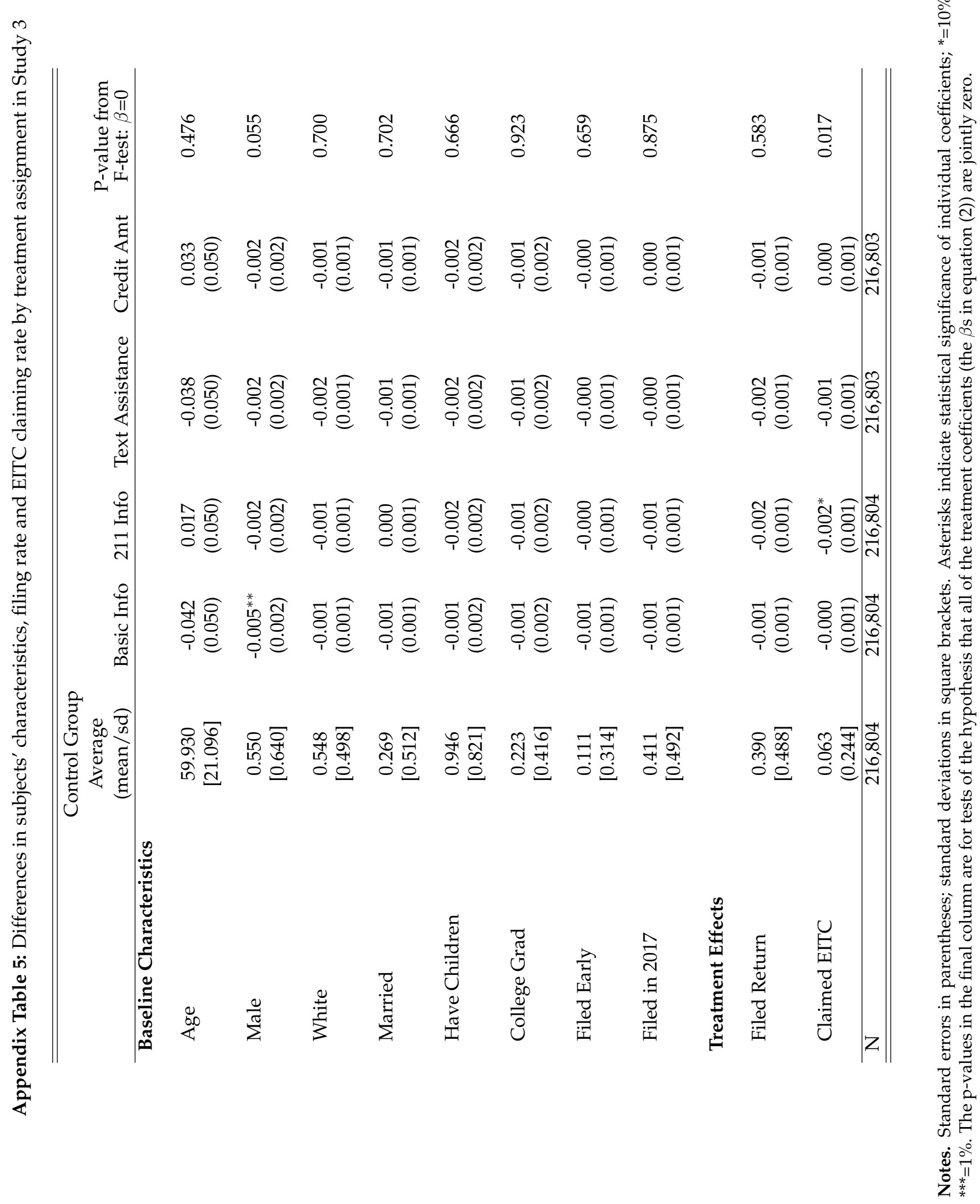




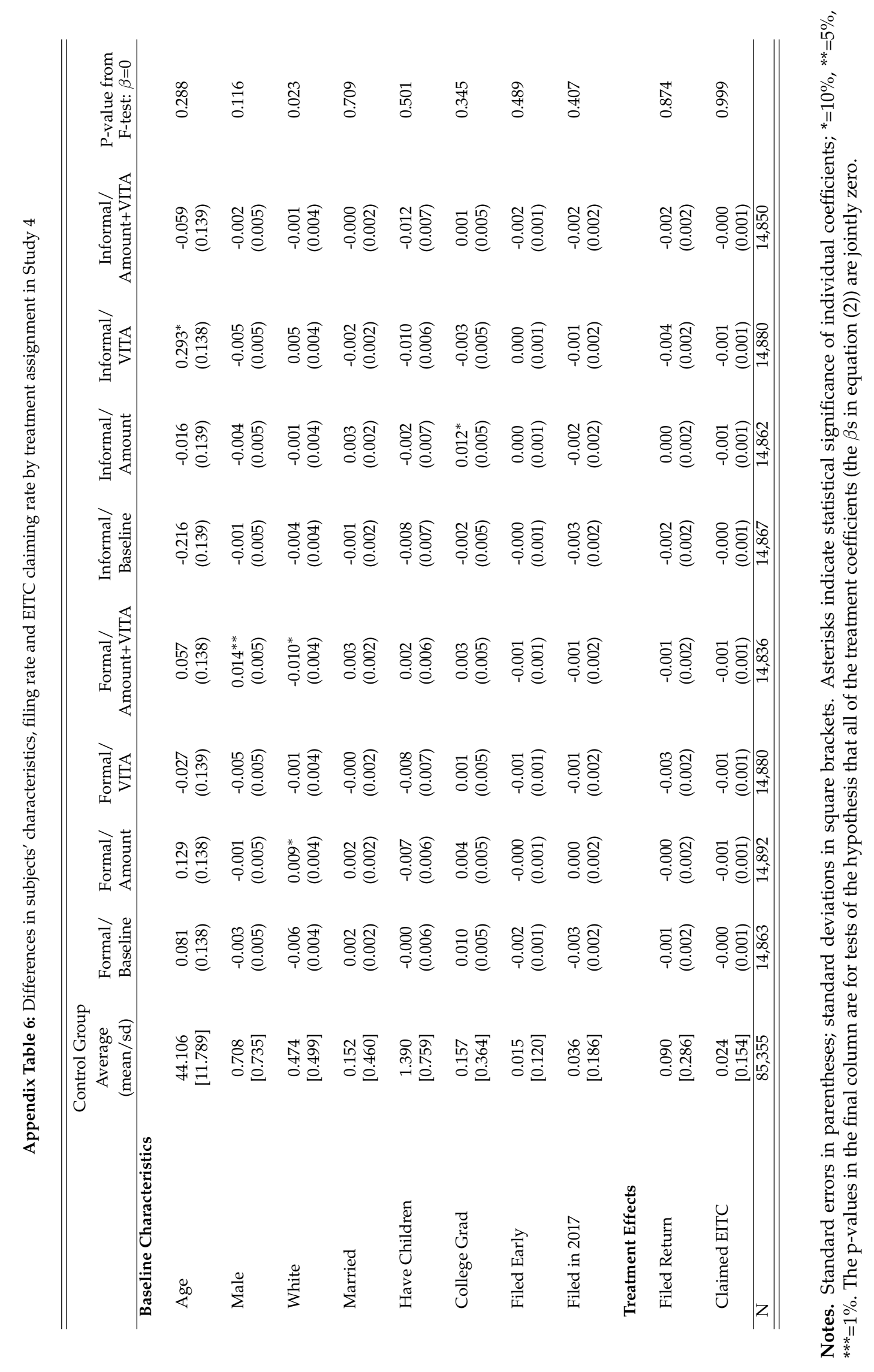


Appendix Table 7: Differences in subjects' baseline characteristics, filing rate and EITC claiming rate by treatment assignment in Study 5, tax year 2017

\begin{tabular}{|c|c|c|c|}
\hline & $\begin{array}{c}\text { Control Group Average } \\
\text { (mean/sd) }\end{array}$ & Basic Text & $\begin{array}{l}\text { P-value from } \\
\text { F-test: } \beta=0\end{array}$ \\
\hline \multicolumn{4}{|l|}{ Baseline Characteristics } \\
\hline Age & $\begin{array}{c}36.95 \\
{[11.07]}\end{array}$ & $\begin{array}{c}0.01 \\
(0.10)\end{array}$ & 0.94 \\
\hline Male & $\begin{array}{c}0.36 \\
{[0.48]}\end{array}$ & $\begin{array}{c}0.00 \\
(0.00)\end{array}$ & 0.96 \\
\hline White & $\begin{array}{c}0.27 \\
{[0.45]}\end{array}$ & $\begin{array}{l}-0.00 \\
(0.00)\end{array}$ & 0.94 \\
\hline English & $\begin{array}{c}0.86 \\
{[0.35]}\end{array}$ & $\begin{array}{c}0.00 \\
(0.00)\end{array}$ & 0.65 \\
\hline Presence of other adults & $\begin{array}{c}0.34 \\
{[0.47]}\end{array}$ & $\begin{array}{l}-0.00 \\
(0.00)\end{array}$ & 0.48 \\
\hline Presence of children & $\begin{array}{c}0.73 \\
{[0.44]}\end{array}$ & $\begin{array}{c}0.00 \\
(0.00)\end{array}$ & 0.98 \\
\hline Filed previous year & $\begin{array}{c}0.70 \\
{[0.46]}\end{array}$ & $\begin{array}{c}0.01 \\
(0.00)\end{array}$ & 0.19 \\
\hline Filed before treatment started & $\begin{array}{c}0.67 \\
{[0.47]}\end{array}$ & $\begin{array}{c}0.00 \\
(0.00)\end{array}$ & 0.75 \\
\hline Predicted total EITC amount & $\begin{array}{c}2915.16 \\
{[2155.56]}\end{array}$ & $\begin{array}{c}-2.89 \\
(11.24)\end{array}$ & 0.80 \\
\hline \multicolumn{4}{|l|}{ Treatment Effects } \\
\hline Filed return & $\begin{array}{c}0.79 \\
{[0.41]}\end{array}$ & $\begin{array}{c}0.01 \\
(0.00)\end{array}$ & 0.17 \\
\hline Claimed EITC & $\begin{array}{c}0.70 \\
{[0.46]}\end{array}$ & $\begin{array}{c}0.00 \\
(0.00)\end{array}$ & 0.91 \\
\hline $\mathrm{N}$ & 19,009 & 19,084 & \\
\hline
\end{tabular}

Notes. Standard errors in parentheses; standard deviations in square brackets. Asterisks indicate statistical significance of individual coefficients; ${ }^{*}=10 \%,{ }^{* *}=5 \%, * * *=1 \%$. The $\mathrm{p}$-values in the final column are for tests of the hypothesis that the treatment effect on the indicated characteristic or outcome is zero. 


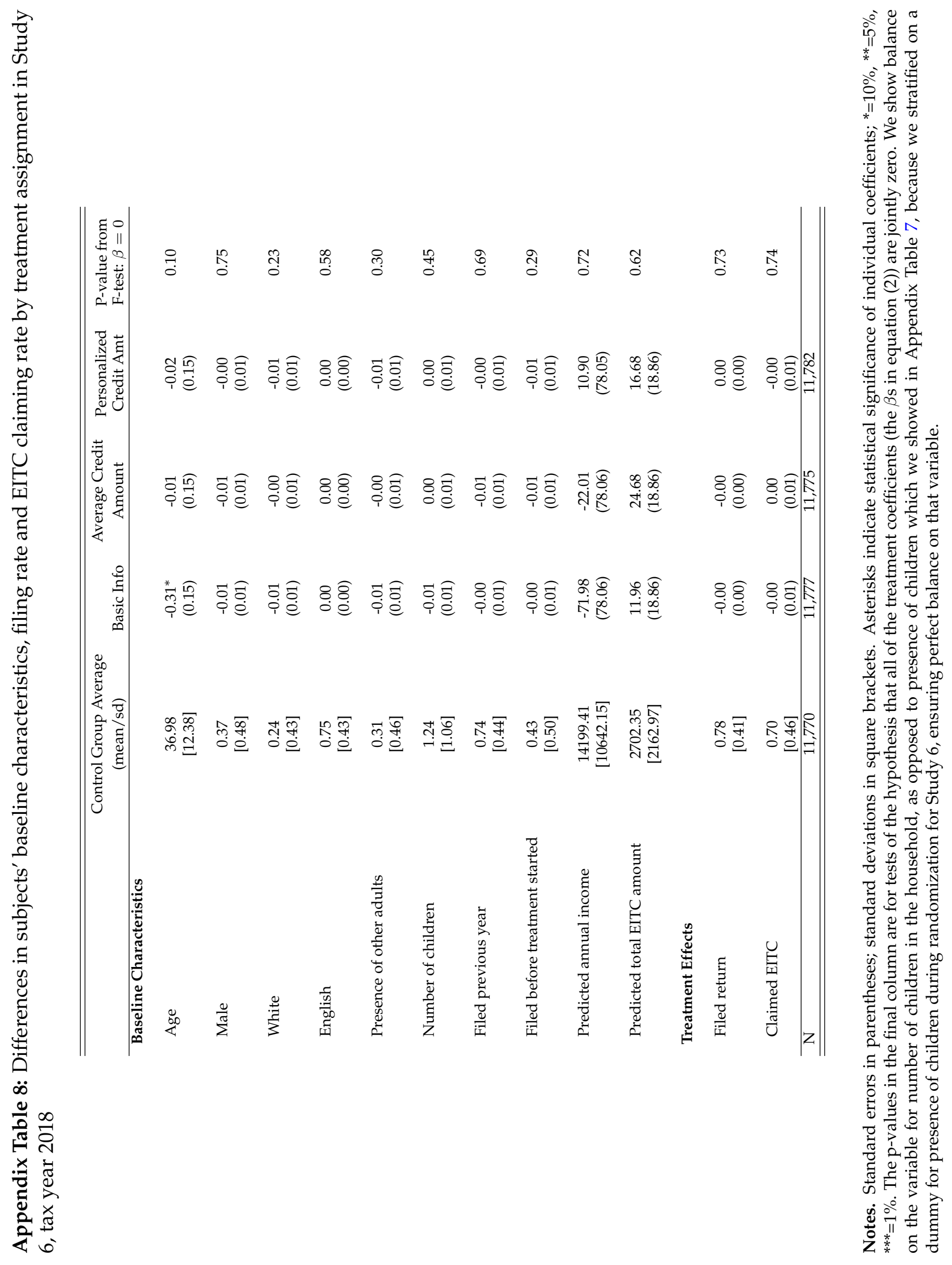


Appendix Figure 1: Estimated income for filers and non-filers in Study 6 control group

Filers

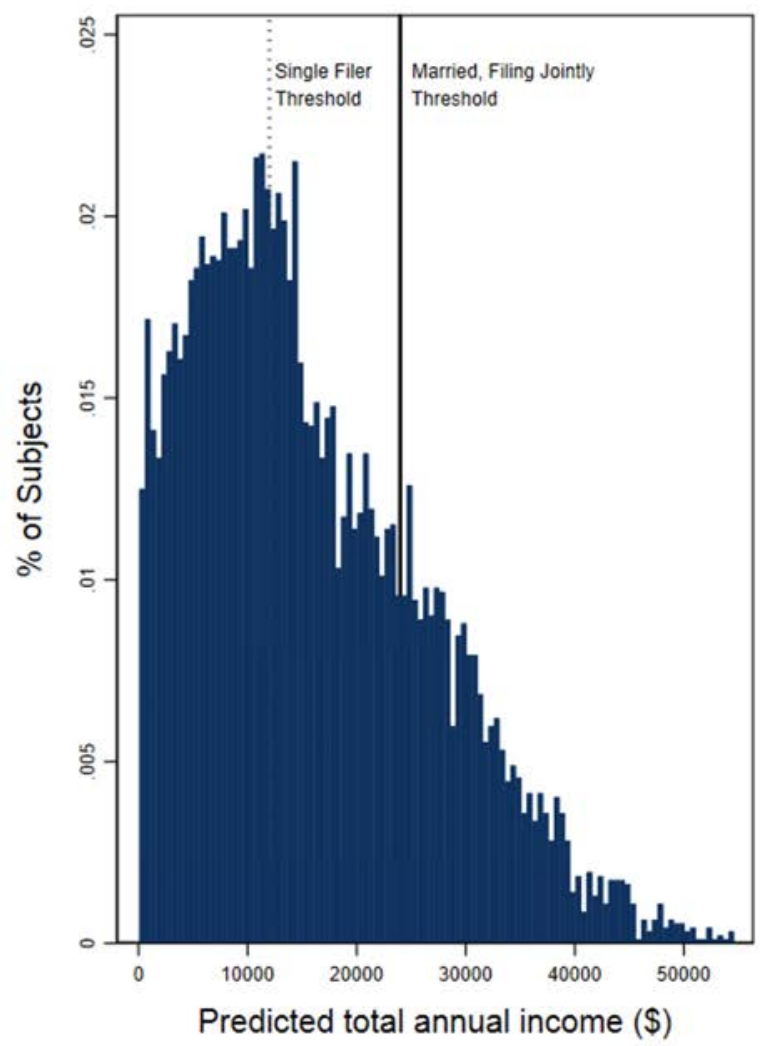

Non-filers

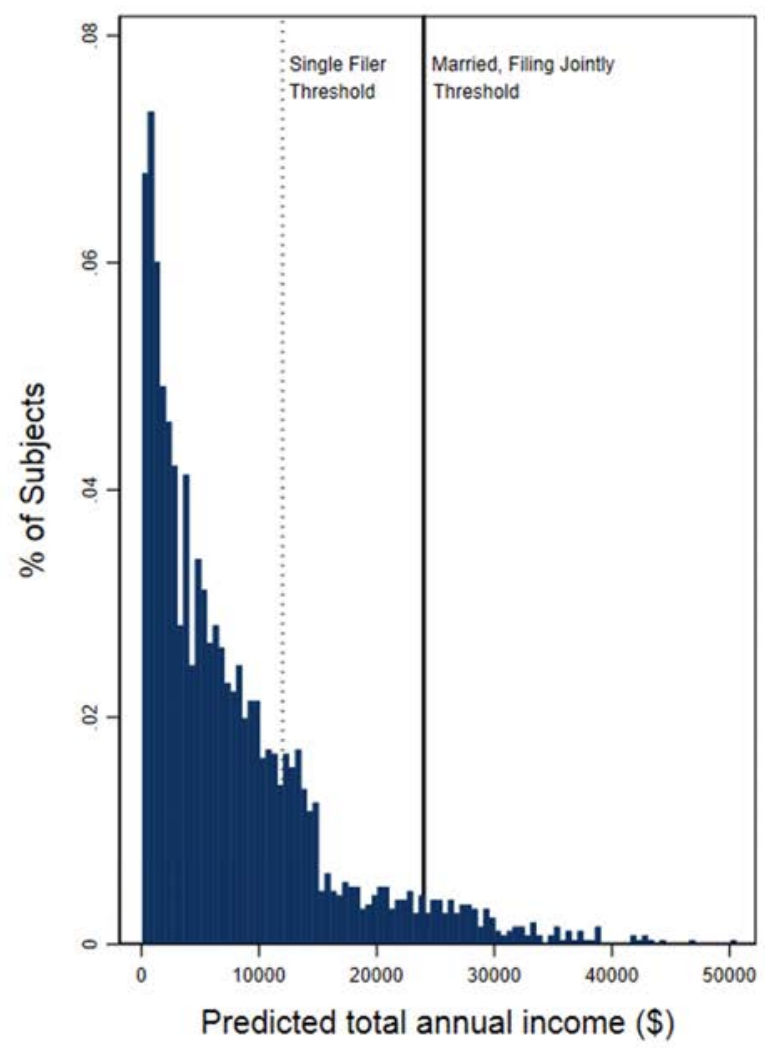

Note: The figure plots the distribution of predicted annual income among subjects in the Study 6 control group separated by those who did and did not file a return. We group households into bins of $\$ 500$. We also mark, using the dotted and solid vertical lines, the income levels in TY 2018 at which the IRS requires single and married taxpayers must file a return, which are $\$ 12,000$ and $\$ 24,000$, respectively. 


\section{Appendix Figure 2: Estimated EITC amount for filers and non-filers in Study 6 control group}
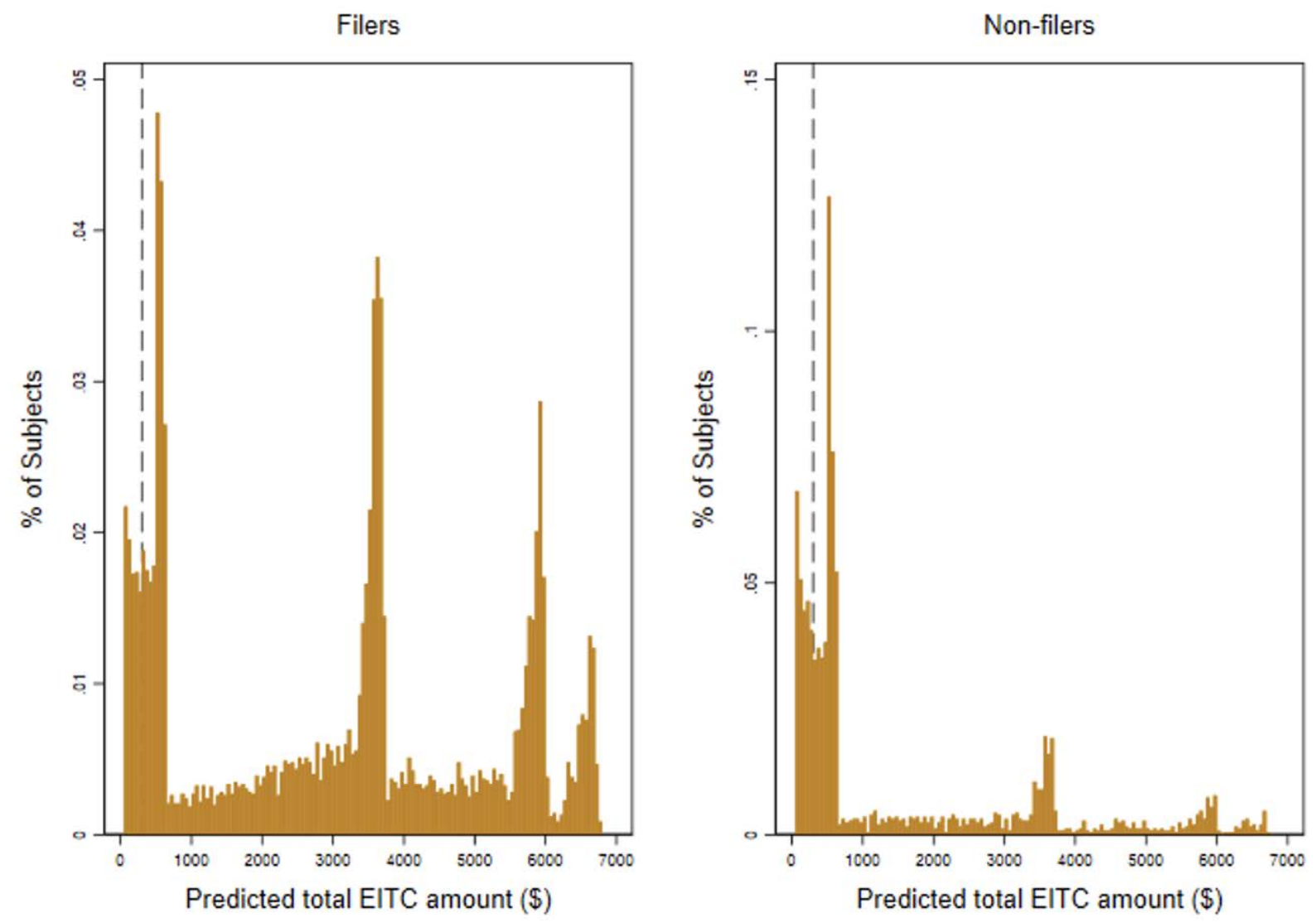

Notes. The figure plots the distribution of estimated EITC eligibility amounts among subjects in the Study 6 control group, separated by those who did and did not file a tax return. We group households into bins of $\$ 50$. The heaps at around $\$ 500, \$ 3,500, \$ 6,000$ and $\$ 6,500$ correspond to the maximum EITCs for families with zero, one, two, or three or more children in TY2018, respectively. The dotted line marks predicted EITC amount of $\$ 300$, representing the approximate cost that families are charged by some for-profit preparers to file their return. 


\section{Appendix Figure 3: Study 1, Golden State Opportunity text messages}

\section{Messages sent in March read:}

Hello, this is a volunteer from CalEITC4Me, we're texting to let people know they may be leaving up to $\$ 6,000$ in tax money on the table, visit our website to see if you are eligible for the EITC and free tax preparation! Have you filed your taxes yet? goo.gl/42PR24

Messages sent in April read:

Hello! My name is <name> with CalEITC4me. Have you filed your taxes yet? You may want to file this year because of the recently expanded California Earned Income Tax Credit! Thousands of Californians are claiming this cash-back credit. You don't want to miss out! If you want to know how to claim it, text me back! We are here to help! Click here! Para Espanol responda con la palabra: Espanol bit.ly/CalEITC4Me 
Appendix Figure 4: Study 2, treatment arm 1 (FTB messenger, formal letter)
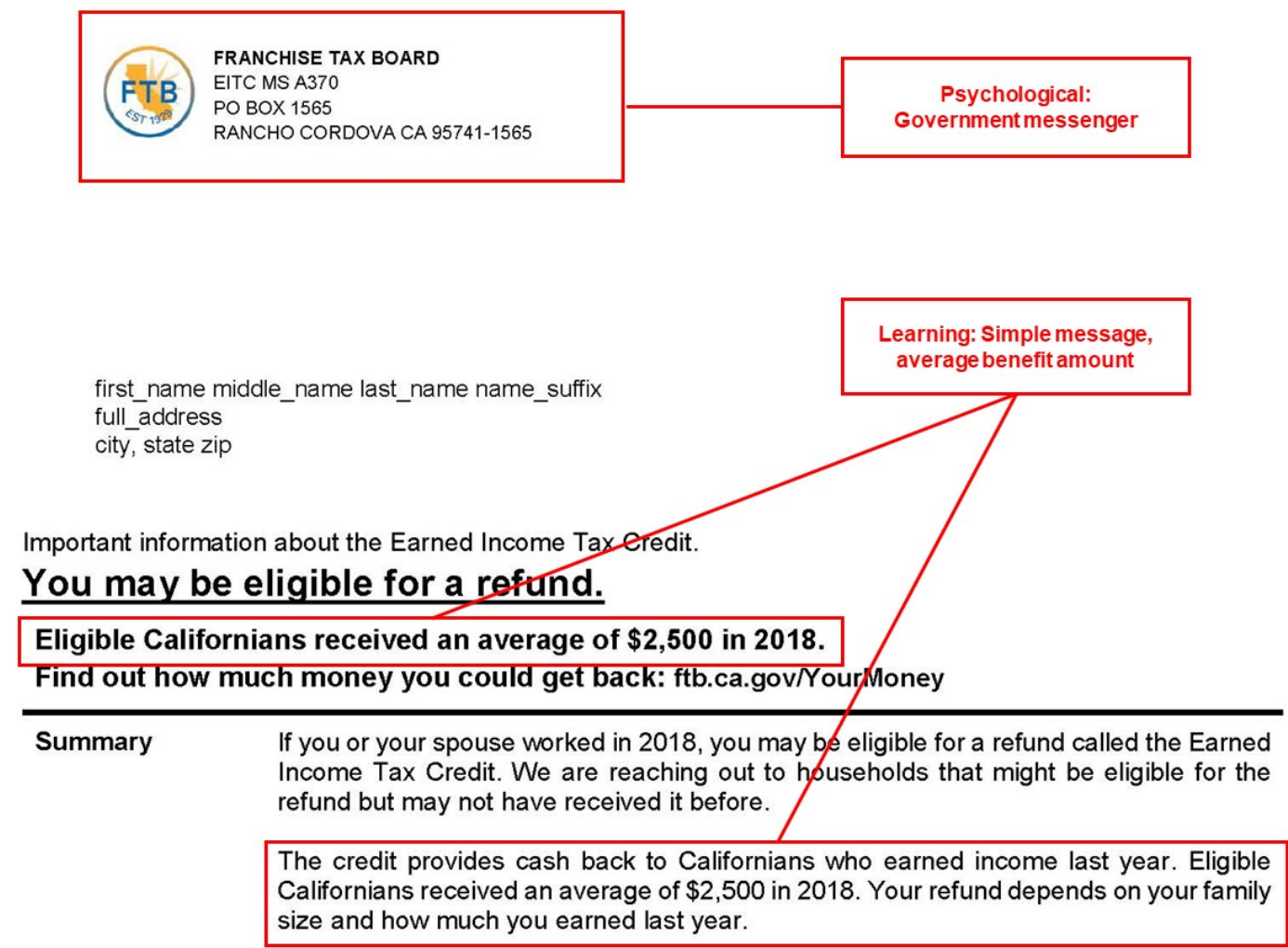

You can claim the refund even if you do not owe taxes. Claiming your refund will not affect your eligibility for other government programs.

Are you eligible? Visit ftb.ca.gov/YourMoney to learn more about the credit and see if you are eligible.

Claim your refund
File your federal and state tax return now to claim your full refund.

A trained tax preparer in your neighborhood can help you file for free. Find free help at:

$\begin{array}{ll}\text { "Site_Name" } & \text { Open "Op } \\ \text { "Address_Line_1" } & \text { "hours_1" } \\ \text { "Address_Line_2" } & \text { "hours_2" } \\ \text { "City", "State» "Zip» } & \text { "hours_3" } \\ \text { Appointment required? } & \text { "hours_4" } \\ \text { "Appointment" } & \text { "hours_5" } \\ & \text { "hours_6" } \\ & \text { "hours_7" }\end{array}$

There may be other convenient locations as well. "call_info_text» to book an appointment or find out what to bring.

\section{Selir Stanislaus}

Selvi Stanislaus

Executive Officer 
Appendix Figure 5: Study 2, treatment arm 2 (FTB messenger, informal letter)

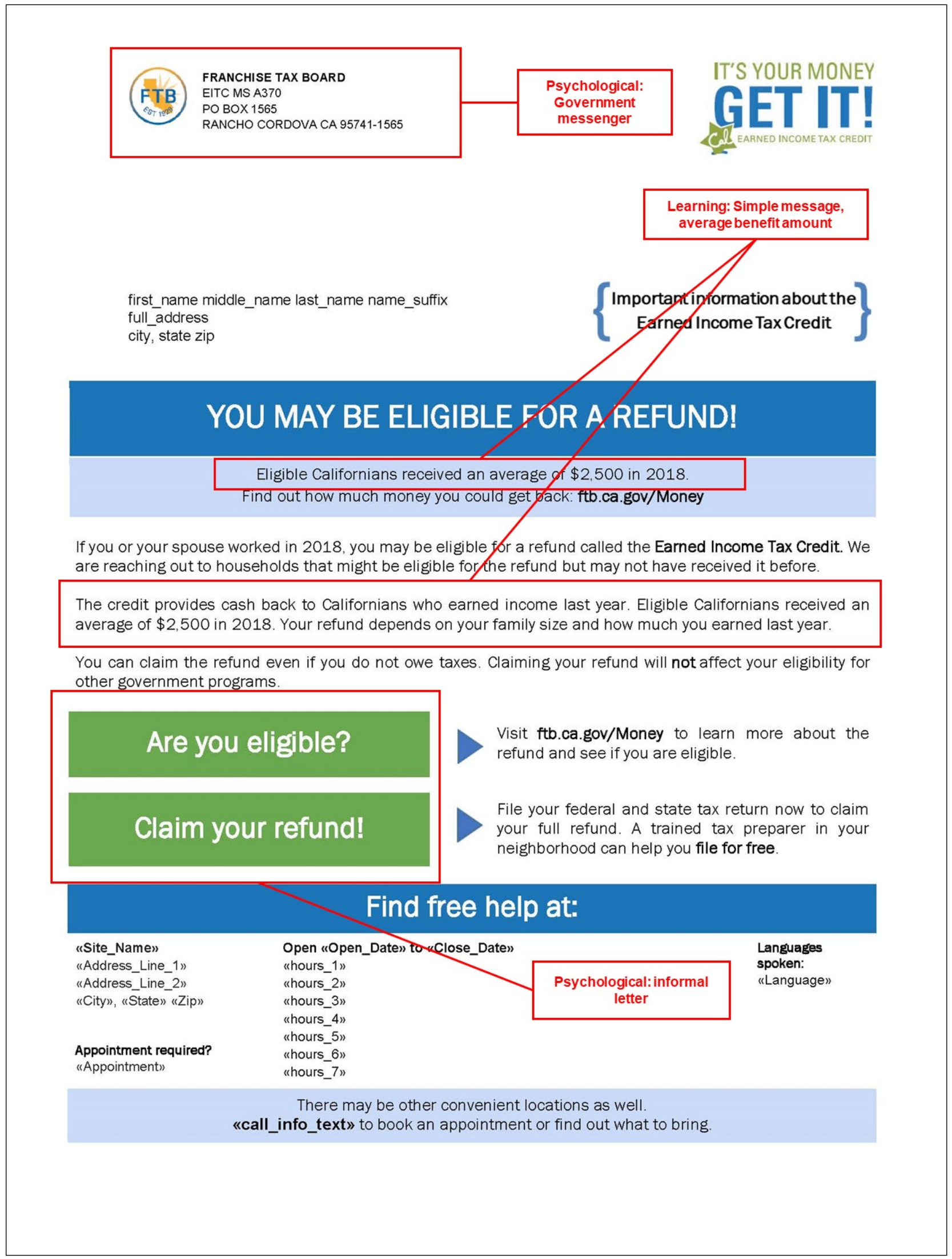


Appendix Figure 6: Study 2, treatment arm 3 (GSO messenger, formal letter)

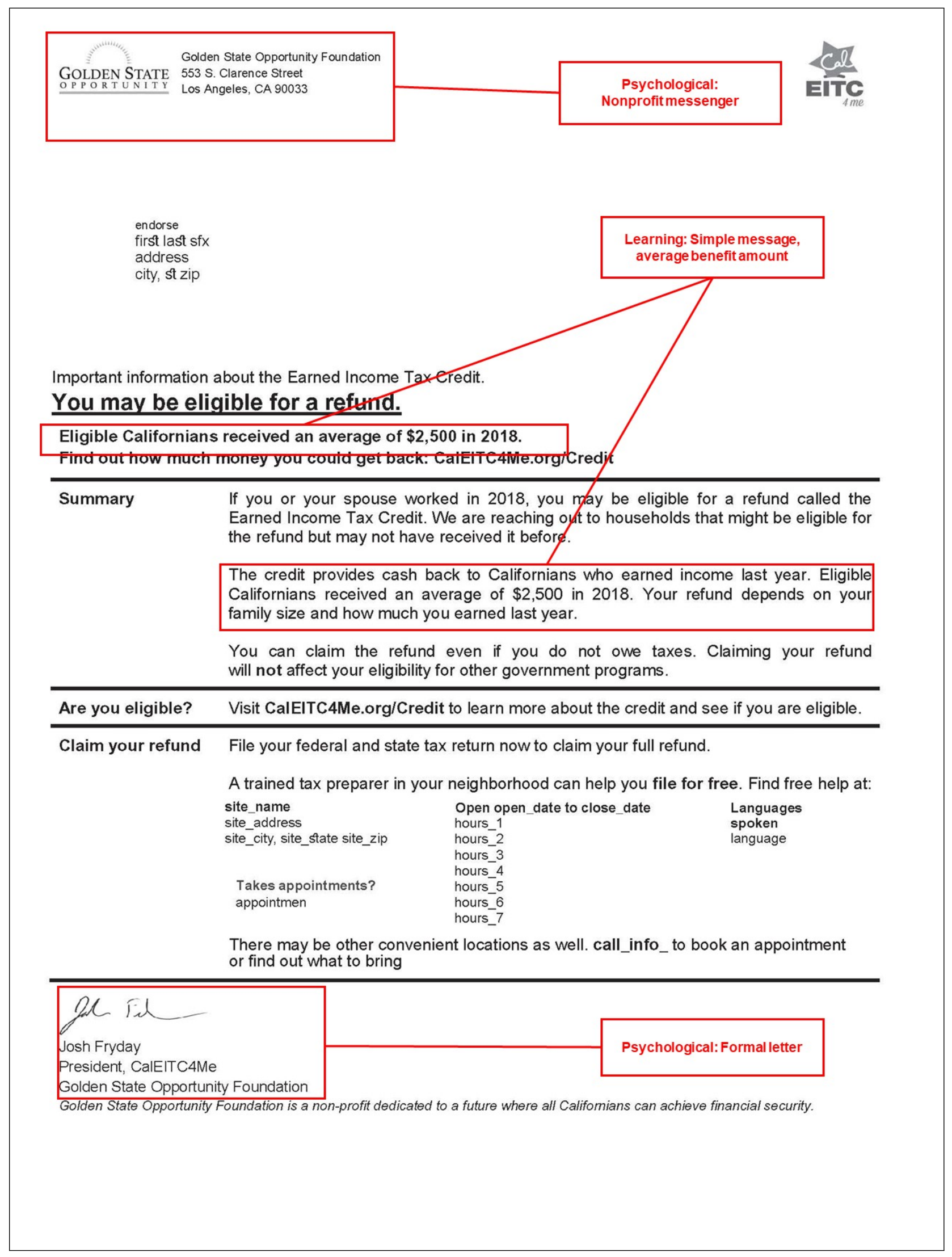


Appendix Figure 7: Study 2, treatment arm 4 (GSO messenger, informal letter)

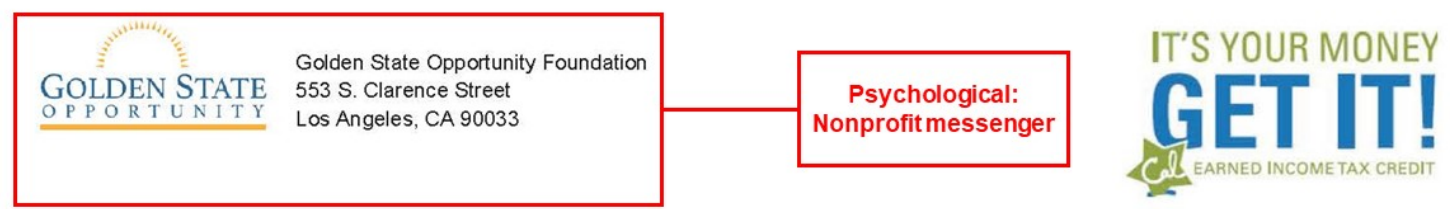

first last sfx

address

city, st zip

\section{YOU MAY BE ELIGIBLE FOR A REFUND!}

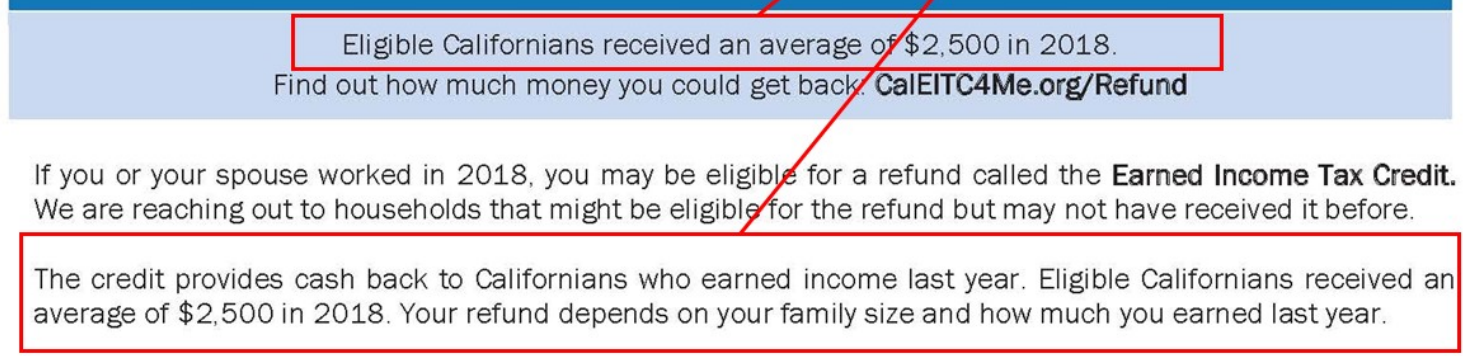

You can claim the refund even if you do not owe taxes. Claiming your refund will not affect your eligibility for other government programs.

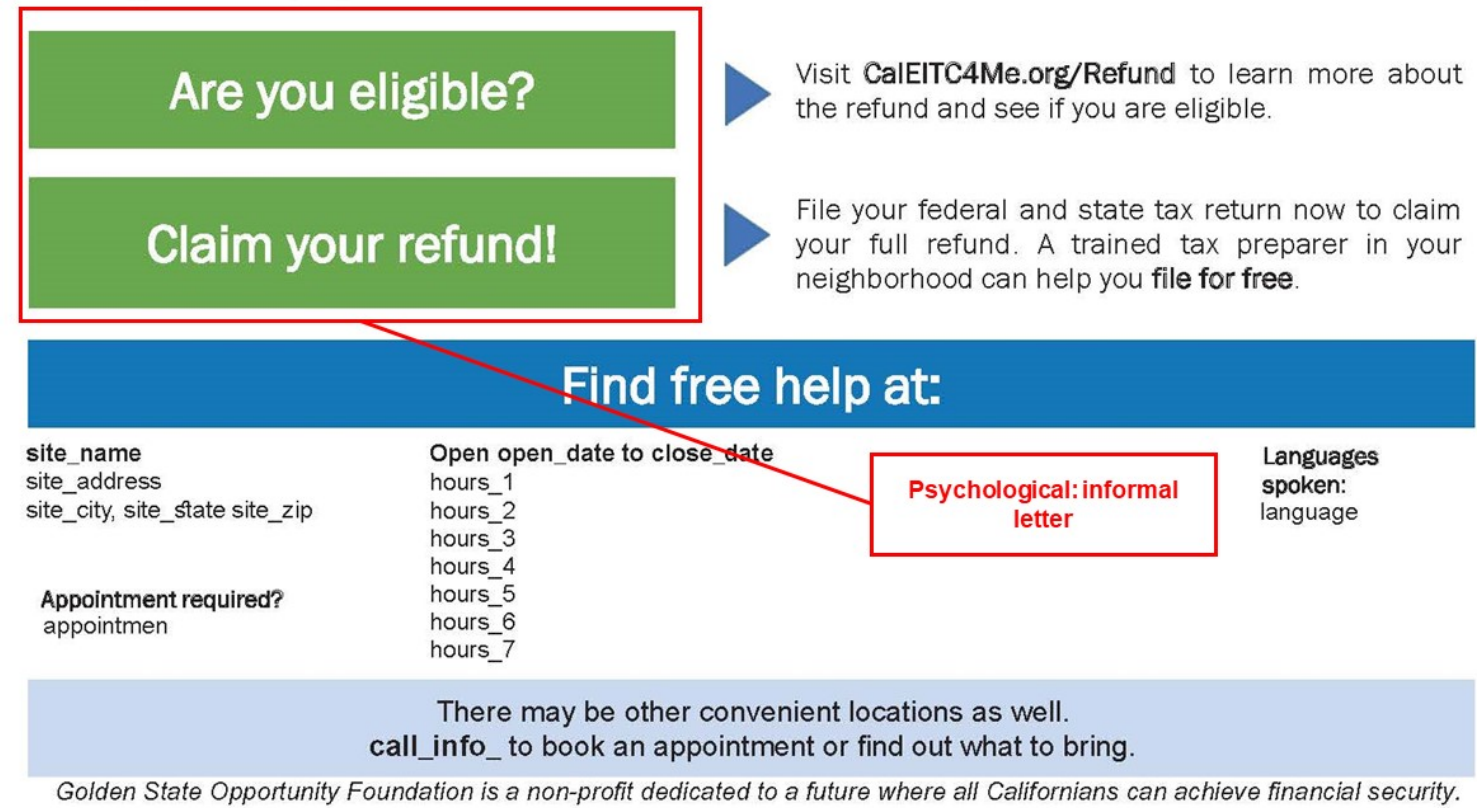


Appendix Figure 8: Study 3, Golden State Opportunity text messages

\section{- Treatment 1: Basic Informational Message + Link}

- Hi-this is <volunteer name>, a volunteer with CalEITC4Me. I'm contacting households who might qualify for a tax refund. Even if you don't owe taxes, you could get cash back by filing a tax return. Visit caleitc4me.org/CashBack to learn more about your eligibility and to claim your EITC refund.

\section{- Treatment 2: Phone number/call option}

- Hi-this is <volunteer name>, a volunteer with CalEITC4Me. I'm contacting households who might qualify for a tax refund. Even if you don't owe taxes, you could get cash back by filing a tax return. Call <local hotline phone number $>$ to get free help with filing your return and to claim your EITC refund.

\section{- Treatment 3: Offer Text-based Assistance}

- Hi-this is <volunteer name>, a volunteer with CalEITC4Me. I'm contacting households who might qualify for a tax refund. Even if you don't owe taxes, you could get cash back by filing a tax return. Text "yes" and I can help you claim your EITC refund.

\section{- Treatment 4: Benefit Value}

- Hi-this is <volunteer name>, a volunteer with CalEITC4Me. I'm contacting households who might qualify for a tax refund. Even if you don't owe taxes, you could get cash back by filing a tax return. Eligible families got back an average of \$2,000 last year. Text "yes" and I can help you claim your EITC refund. 
Appendix Figure 9: Study 4, treatment arm 1 (formal, simple)

\section{FRANCHISE TAX BOARD}

FORMAL -SIMPLE

EITC MS A370

PO BOX 1565

RANCHO CORDOVA CA 95741-1565

first_name middle_name last_name name_suffix

full_address

city, state zip

Important information about the Earned Income Tax Credit.

You may be eligible for a refund.

\begin{tabular}{ll}
\hline Summary & $\begin{array}{l}\text { If you or your spouse worked in 2018, you may be eligible for a refund called the Earned } \\
\text { Income Tax Credit. We are reaching out to households that might be eligible for the } \\
\text { refund but may not have received it before. }\end{array}$
\end{tabular}

The credit provides cash back to Californians who earned income last year. Your refund depends on your family size and how much you earned last year.

You can claim the refund even if you do not owe taxes. Claiming your refund will not affect your eligibility for other government programs.

\begin{tabular}{ll|}
\hline Are you eligible? & Visit ftb.ca.gov/Credit to learn more about the credit and see if you are eligible. \\
\hline Claim your refund & File your federal and state tax return to claim your full refund. You can file for free. \\
& For free tax preparation help, visit: ftb.ca.gov/Credit \\
\hline Selir Stanislars & $\begin{array}{c}\text { URL unique to each } \\
\text { treatment arm }\end{array}$ \\
\end{tabular}

Selvi Stanislaus

Executive Officer

California Franchise Tax Board

中文| 한국어 | Русский | Tiếng Việt $\rightarrow$ ftb.ca.gov/Lang1 
Appendix Figure 10: Study 4, treatment arm 2 (formal, credit amount)

FRANCHISE TAX BOARD

first_name middle_name last_name name_suffix full address

city, state zip

Important information about the Earned Income Tax Credit.

You may be eligible for a refund.

Eligible Californians received an average of \$2,500 in 2018.

Find out how much money you could get back: ftb.ca.gov/Earn

If you or your spouse worked in 2018, you may be eligible for a refund called the Earned
Income Tax Credit. We are reaching out to households that might be eligible for the
refund but may not have received it before.
$\begin{aligned} & \text { The credit provides cash back to Californians who earned income last year. Eligible } \\ & \text { Californians received an average of } \$ 2,500 \text { in 2018. Your refund depends on your } \\ & \text { family size and how much you earned last year. }\end{aligned}$

You can claim the refund even if you do not owe taxes. Claiming your refund will not affect your eligibility for other government programs.

\begin{tabular}{ll}
\hline Are you eligible? & Visit ftb.ca.gov/Earn to learn more about the credit and see if you are eligible. \\
\hline Claim your refund & File your federal and state tax return to claim your full refund. You can file for free. \\
& For free tax preparation help, visit: ftb.ca.gov/Earn \\
\hline
\end{tabular}

\section{Selir Stanislaus}

Selvi Stanislaus

Executive Officer

California Franchise Tax Board

中文 | 한국어 | Русский | Tiếng Việt $\rightarrow$ ftb.ca.gov/Lang2 
Appendix Figure 11: Study 4, treatment arm 3 (formal, VITA info)

FRANCHISE TAX BOARD

FORMAL - VITA

EITC MS A370

PO BOX 1565

RANCHO CORDOVA CA 95741-1565

first_name middle_name last_name name_suffix

full_address

city, state zip

Important information about the Earned Income Tax Credit.

You may be eligible for a refund.

Summary

If you or your spouse worked in 2018, you may be eligib/e for a refund called the Earned Income Tax Credit. We are reaching out to households that might be eligible for the refund but may not have received it before.

The credit provides cash back to Californians who garned income last year. Your refund depends on your family size and how much you earned last year.

You can claim the refund even if you do not owe taxes. Claiming your refund will not affect your eligibility for other government programs.

\begin{tabular}{|c|c|c|c|}
\hline Are you eligible? & \multicolumn{3}{|c|}{ Visit ftb.ca.gov/Refund to learn more about thle credit and see if you are eligible. } \\
\hline \multirow[t]{4}{*}{ Claim your refund } & \multicolumn{3}{|c|}{ File your federal and state tax return now to claim your full refund. } \\
\hline & \multicolumn{3}{|c|}{$\begin{array}{l}\text { A trained tax preparer in your neighborhood can help you file for free. Find free help } \\
\text { at: }\end{array}$} \\
\hline & $\begin{array}{l}\text { "Site_Name" } \\
\text { "Address_Line_1" } \\
\text { "Address_Line_2" } \\
\text { "City", "State" "Zip" } \\
\text { Appointment required? } \\
\text { "Appointment" }\end{array}$ & $\begin{array}{l}\text { Open "Open_Date" to "Close_Date" } \\
\text { "hours_1" } \\
\text { "hours_2" } \\
\text { "hours_3" } \\
\text { "hours_4" } \\
\text { "hours_5" } \\
\text { "hours_6" } \\
\text { "hours_7" }\end{array}$ & $\begin{array}{l}\text { Languages } \\
\text { spoken } \\
\text { "Language } \\
\text { " }\end{array}$ \\
\hline & \multicolumn{3}{|c|}{$\begin{array}{l}\text { There may be other convenient locations as well. "call_info_text» to book an } \\
\text { appointment or find out what to bring. }\end{array}$} \\
\hline
\end{tabular}

\section{Selir Stanislaus}

Selvi Stanislaus

Executive Officer

California Franchise Tax Board

中文 | 한국어 | Русский | Tiếng Việt $\rightarrow$ ftb.ca.gov/Lang3 
Appendix Figure 12: Study 4, treatment arm 4 (formal, credit amount + VITA info)

FRANCHISE TAX BOARD

first_name middle_name last_name name_suffix full address

city, state zip

Important information about the Earned Income Tax Credit.

You may be eligible for a refund. Eligible Californians received an average of \$2,500 in 2018. Find out how much money you could get back: ftb.ca.gov/EITC

Summary

If you or your spouse worked in 2018, you may be/eligible for a refund called the Earned Income Tax Credit. We are reaching out to households that might be eligible for the refund but may not have received it before.

The credit provides cash back to Californians who earned income last year. Eligible Californians received an average of $\$ 2,500$ in 2018 . Your refund depends on your family size and how much you earned last year.

You can claim the refund even if you do not owe taxes. Claiming your refund will not affect your eligibility for other government programs.

Are you eligible? Visit ftb.ca.gov/EITC to learn more about the credit and see if you are eligible.

Claim your refund
File your federal and state tax return now to claim your full refund.

A trained tax preparer in your neighborhood can help you file for free. Find free help at:

$\begin{array}{ll}\text { "Site_Name" } & \text { Open "Ope } \\ \text { "Address_Line_1" } & \text { "hours_1" } \\ \text { "Address_Line_2" } & \text { "hours_2" } \\ \text { "City», "State" "Zip" } & \text { "hours_3" } \\ \text { Appointment required? } & \text { "hours_4" } \\ \text { "Appointment" } & \text { "hours_5" } \\ & \text { "hours_6" }\end{array}$

There may be other convenient locations as well. «call_info_text» to book an appointment or find out what to bring.

\section{Selir Stanislans}

Selvi Stanislaus

Executive Officer

California Franchise Tax Board

Compliance: Iocal in-person free tax preparation information

中文 | 한국어 | Русский | Tiếng Việt $\rightarrow \quad$ ftb.ca.gov/Lang4 
Appendix Figure 13: Study 4, treatment arm 5 (informal, simple)

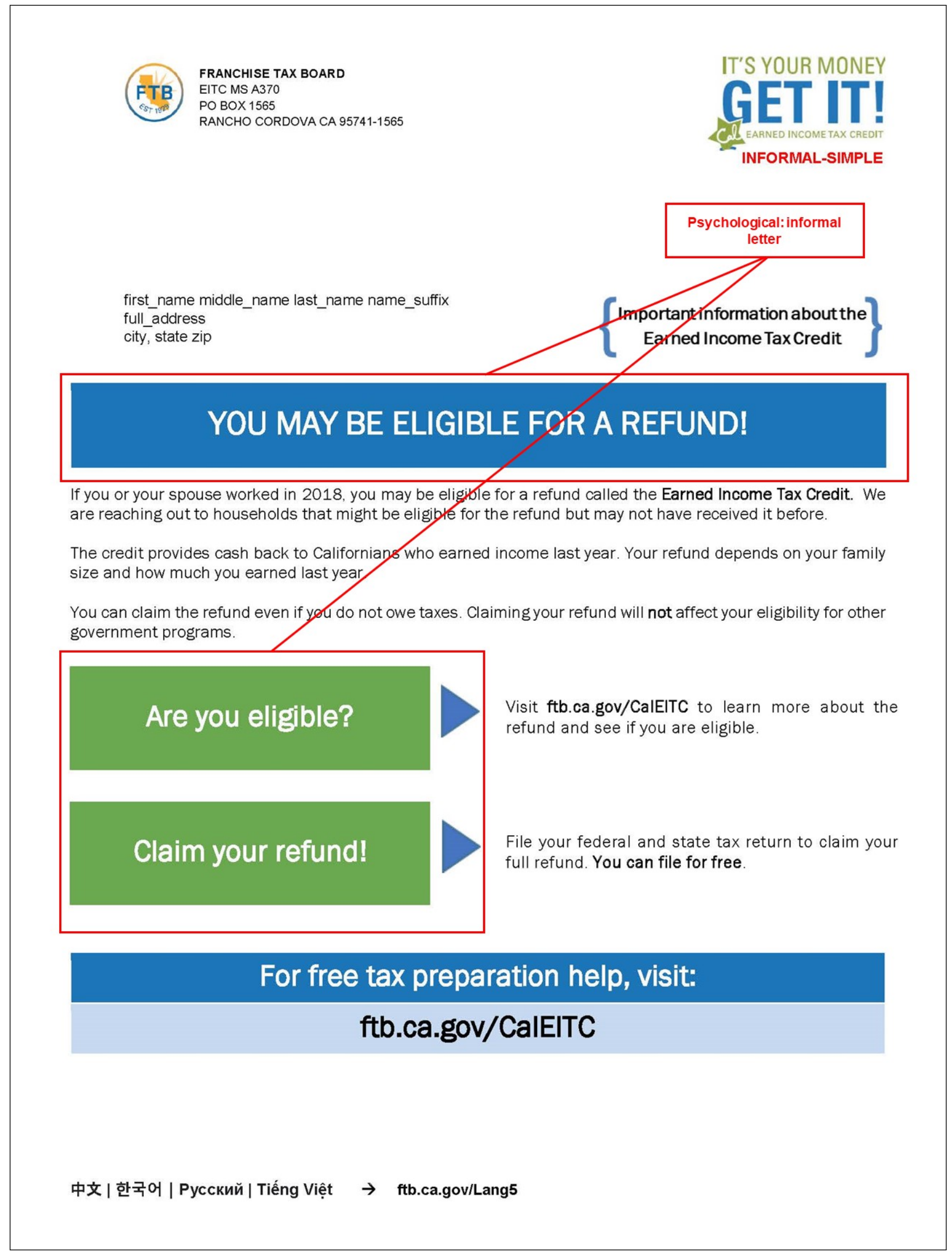


Appendix Figure 14: Study 4, treatment arm 6 (informal, credit amount)

FRANCHISE TAX BOARD

FTB EITC MS A370

PO BOX 1565

RANCHO CORDOVA CA 95741-1565

INFORMAL - BENEFIT

first name middle name last name name suffix

full_address

city, state zip

Learning: average benefit amount

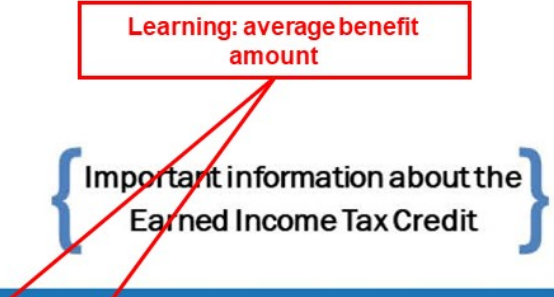

\section{YOU MAY BE ELIGIBLE FOR A REFUND!}

Eligible Californians received an average of $\$ 2,500$ in 2018.

Find out how much money you could get back: ftb.ca.gov/EarnIt

If you or your spouse worked in 2018, you may be eligible for a refund called the Earned Income Tax Credit. We are reaching out to households that might be eligible for the refund but may not have received it before.

The credit provides cash back to Californians who earned income last year. Eligible Californians received an average of $\$ 2,500$ in 2018 . Your refund depends on your family size and how much you earned last year.

You can claim the refund even if you do not owe taxes. Claiming your refund will not affect your eligibility for other government programs.

Are you eligible?

\section{Claim your refund!}

Visit ftb.ca.gov/EarnIt to learn more about th credit and see if you are eligible.

File your federal and state tax return to claim your full refund. You can file for free.

\section{For free tax preparation help, visit:}

ftb.ca.gov/EarnIt

中文 | 한국어 | Русский | Tiếng Việt $\rightarrow$ ftb.ca.gov/Lang6 


\section{Appendix Figure 15: Study 4, treatment arm 7 (informal, VITA info)}

FRANCHISE TAX BOARD

FTB EITC MS A370

PO BOX 1565

RANCHO CORDOVA CA 95741-1565

\section{YOU MAY BE ELIGIBLE FOR A REFUND!}

If you or your spouse worked in 2018, you may be eligible for a refund called the Earned Income Tax Credit. We are reaching out to households that might be eligible for the refund but may not have received it before.

The credit provides cash back to Californians who earned income last year. Your refund depends on your family size and how much you earned last year.

You can claim the refund even if you do not owe taxes. Claiming your refund will not affect your eligibility for other government programs.

Compliance: Local in-person free tax preparation information

\section{Are you eligible?}

\section{Claim your refund!}

\section{Find free help at:}

\section{"Site_Name»}

"Address_Line_1"

"Address_Line_2"

"City», "State» «Zip»

"Appointment»

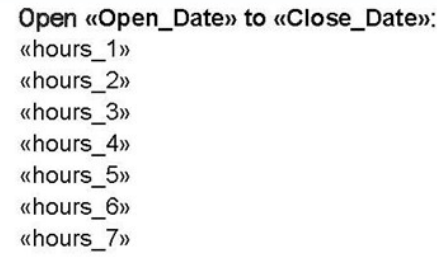

There may be other convenient locations as well. «call_info_text» to book an appointment or find out what to bring
Languages spoken: "Language»

\section{中文 | 한국어 | Русский | Tiếng Việt $\rightarrow$ ftb.ca.gov/Lang7}


Appendix Figure 16: Study 4, treatment arm 8 (informal, credit amount + VITA info)

FRANCHISE TAX BOARD

EITC MS A370

PO BOX 1565

RANCHO CORDOVA CA 95741-1565

first_name middle_name last_name name_suffix full_address

city, state zip

\section{YOU MAY BE ELIGIBLE FOR A REFUND!}

\section{Eligible Californians received an average $\varnothing \$ \$ 2,500$ in 2018. Find out how much money you could get back: ftb.ca.gov/CashBack}

If you or your spouse worked in 2018 , you may be eligible fof a refund called the Earned Income Tax Credit. We are reaching out to households that might be eligible for the refund but may not have received it before.

The credit provides cash back to Californians who earned income last year. Eligible Californians received an average of $\$ 2,500$ in 2018 . Your refund depends on your family size and how much you earned last year.

You can claim the refund even if you do not owe taxes. Claiming your refund will not affect your eligibility for other government programs.

\section{Are you eligible?}

\section{Claim your refund!}

Compliance: local in-person free tax preparation information

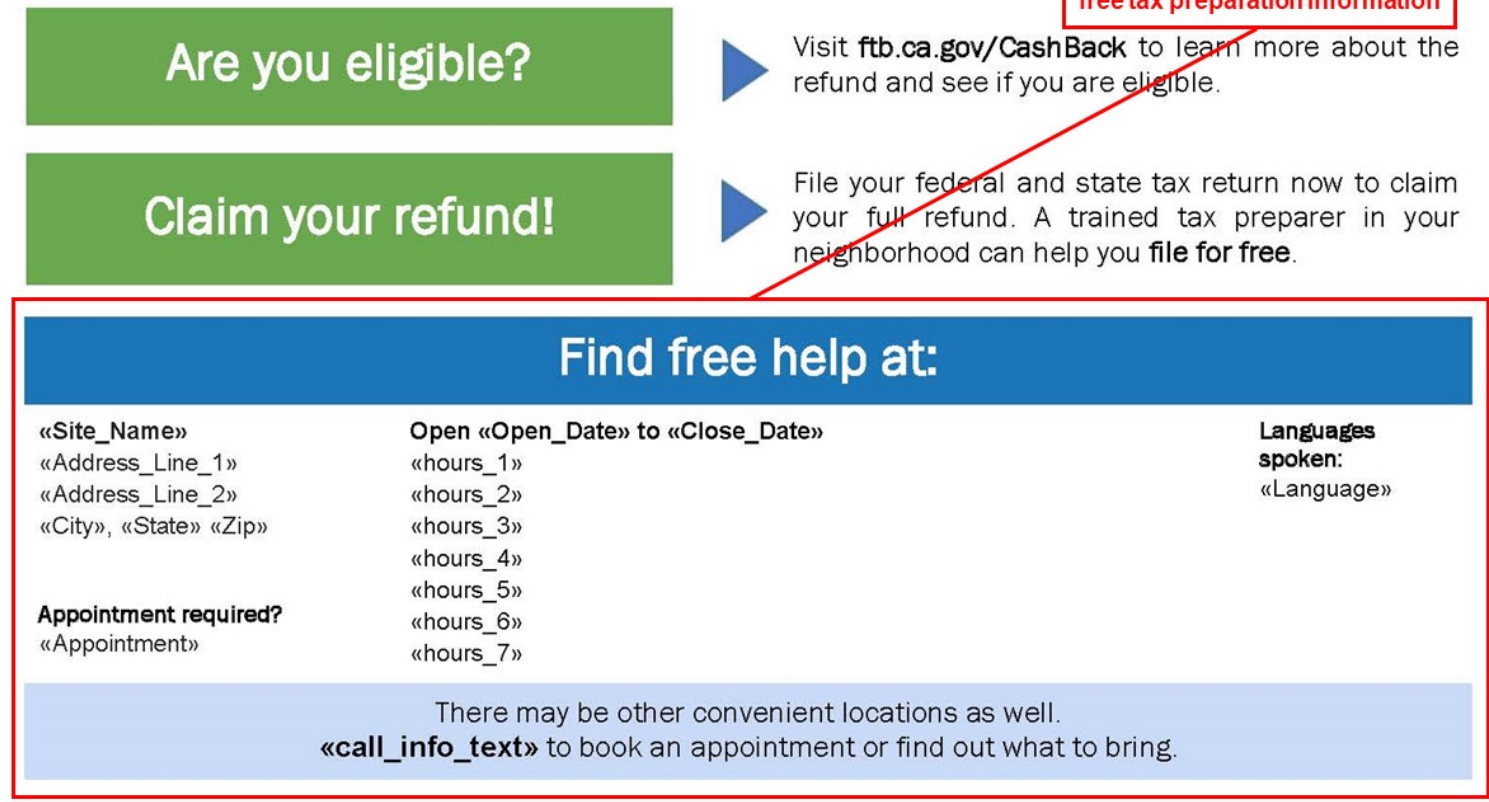

中文 | 한국어 | Русский | Tiếng Việt $\rightarrow \quad$ ftb.ca.gov/Lang8 
Appendix Figure 17: Study 5, CA Department of Social Services/CalFresh text messages, tax year 2017

\section{Text 1:}

$H i$, this is <county>. Have you claimed your tax refund? We estimate you're owed about $\$ x, x x x$ from state and federal earned income tax credits. File your taxes to get the refund you earned! Reply " 1 " to learn how to get your taxes done for free or "2" to stop these texts. Standard messaging rates apply.

Text 2:

You can use free online software to prepare your taxes at www.myfreetaxes.org (sponsored by the United Way). For in-person assistance, find the closest volunteer site at irs.treasury.gov/freetaxprep. Would you like information for a nearby site? If yes, reply " 1 ".

Note: Those who responded with a "1" to the first message were sent the second message. Those who responded with a " 1 " to the second message were sent the address and hours of the closest VITA site to the client's 9 digit zip code. When that site required appointments, the text also included a link for registration. Texts were sent in English or Spanish, depending on the language indicated in the CalFresh record, and were delivered over two days in a single blast in March 2018. 
Appendix Figure 18: Study 6, CA Department of Social Services/CalFresh text messages, tax year 2018

- Treatment 1: Control Text

- Text 1: Hi <name>. This is <county name $>$ County. You may qualify for cash back thanks to tax credits.

- Text 2: Claim your refund by filing a tax return. See if you're eligible at caleitc4me.org/Cash. Call 211 to file your taxes for free.

\section{- Treatment 2: Average Benefit}

- Text 1: Hi <name>. This is <county name> County. You may qualify for cash back thanks to tax credits. Eligible families got back $\$ 2,500$ on average last year.

- Text 2: Claim your refund by filing a tax return. See if you're eligible at caleitc4me.org/YourMoney. Call 211 to file your taxes for free.

\section{- Treatment 3: Personalized Benefit}

- Text 1: Hi <name>. This is <county name $>$ County. You may qualify for cash back thanks to tax credits. Based on our records, you could get back $<\$$ credit amount $>$.

- Text 2: Claim your refund by filing a tax return. See if you're eligible at caleitc4me.org/Money. Call 211 to file your taxes for free. 


\section{References}

National Society of Accountants. (n.d.). 2016-2017 Income \& Fees of Accountants and Tax Preparers in Public Practice Survey Report.

US Government Accountability Office. (2014). Paid Tax Return Preparers: In a Limited Study, Preparers Made Significant Errors, testimony presented to the US Senate Committee on Finance (GAO-14-467T). 